\title{
Incest: a crime of violence, $1840-1940$
}

Not until the second half of the nineteenth century did Swedish agrarian society enter a new age of industrialisation and urbanisation. The population grew steadily, which led to increasing social problems in the country. In the countryside, an ever-increasing proportion of the population lived in poverty, and in the cities the authorities struggled against overcrowding and worsening hygienic conditions as well as against rising crime, alcoholism, and prostitution. The number of marriages decreased while the number of illegitimate children rose, which reinforced the impression of a society in moral decline. ${ }^{1}$ In this context, the lower classes were frequently portrayed as a menace to bourgeois society. The poor were believed to threaten society economically through the cost of poor relief and the fight against crime, but also morally through their lazy and sinful ways of life. ${ }^{2}$

Liberal ideas, whose proponents advocated greater freedom and equality in society, slowly gained ground in relation to the conservative forces that protected the older social order. The old society of estates lost its legitimacy, and in 1866 the Riksdag of Estates was abolished in favour of a parliament with two chambers. The guild system was abolished and freedom to conduct business was introduced, entailing greater social mobility. During the same period there was a clear shift in power from the king to the Riksdag and the government. ${ }^{3}$ Ideologically speaking, the unified Lutheran church

1 Levin 1994, p. 45. The population increase was at its greatest during the first half of the nineteenth century. The 'social question' had been debated even before industrialisation and urbanisation made the situation in the cities worse. For the poverty debate during the whole of the nineteenth century, see Petersson 1983.

2 Sjögren 1997, pp. 22, 158; Nilsson 2008, p. 141.

3 Inger 2011, pp. $208 \mathrm{f}$. 
was challenged partly by various nonconformist denominations and partly by an increased incidence of atheism, which led to a general secularisation of society. This did not mean that religion disappeared. Rather, it changed character in that the significance of religion in the public space dwindled while it continued to be an important part of the lives of individuals and groups. Religious worship became a matter of personal allegiance. This development has been described as a privatisation of religion. ${ }^{4}$ Liberal and nonconformist groups questioned the prevailing religious compulsory system. As a result, the regulatory frameworks of several religious rites that had previously been obligatory, for instance communion and christenings, were loosened. ${ }^{5}$ In 1908, civil marriage was introduced as an alternative to church weddings. ${ }^{6}$

The balance of power between the sexes changed as well. Various reforms boosted women's opportunities to support themselves, and at the same time men's guardianship over them was reduced. ${ }^{7}$ The year 1919 saw the introduction of female suffrage in parliamentary elections. Even so, marriage as an institution continued to be regarded as one of the mainstays of society. ${ }^{8}$

Swedish society was thus transformed on a number of levels, economically and demographically as well as ideologically and culturally. The third and last part of this study examines how the general attitude to and assessment of incestuous relationships were affected by these revolutionary social developments. The investigation continues where the previous part ended, in the middle of the nineteenth century, with the then topical debate on potential liberalisations of the affinity prohibitions in collateral and diagonal degrees.

4 The changed role of religion in society has also been described as a pluralisation or a feminisation. On the changed role of religion in European society, see, e.g., Mcleod 2000a; Mcleod 2000b; Brown 2001. Swedish developments around the turn of the century in 1900 have been described in Bexell 2008.

5 Bexell 2008, p. 64; Inger 2011, pp. $240 f$.

6 Inger 2011, p. 219.

7 For instance, in 1845 equal rights to matrimonial property and rights of inheritance were introduced for men and women. Women gained their own majority gradually through reforms in 1858, 1863, 1874, and 1884 . Inger 2011, pp. 218, 244.

8 Inger 2011, p. 248. 


\section{An intermediate period, 1840-72}

\section{The Penal Act of 1864}

During the first half of the nineteenth century, a legislative committee worked on proposals for a new civil and penal act in Sweden. The first proposal was presented as early as 1832 , but it was not until 1864 that a new penal act could be adopted by the Riksdag. In the preparatory legislative work, the legislators were first and foremost inspired by German jurisprudential debates. ${ }^{9}$ From a socio-economic perspective, proponents of the new ideas argued that it would be better if punishments were focused on improving the criminal and preventing new crimes, rather than on avenging criminal acts that had been committed. The retention or abolition of capital punishment continued to be debated vigorously, while public-shaming punishments and corporal punishments were increasingly questioned. Punishments involving flogging were no longer considered compatible with 'the sense of justice and way of thinking of the Swedish people'. It was feared that corporal punishment would make the criminal unfavourably disposed towards society, which would lead to the commission of new crimes. ${ }^{10}$ With milder punishments, which were nevertheless in reasonable proportion to the crime, it was hoped that general criminality could be reduced. ${ }^{11}$ However, not all legislators embraced these new ideas, and the Act of 1864 became a compromise between older and newer criminological influences. ${ }^{12}$

Unlike the state of things in previous periods, the penalties imposed were now put in relation to the injury or damage that various crimes had caused to people or property. This new way of thinking entailed changes in the status of religious and moral crimes. They were still believed to have a detrimental influence on society from a moral perspective; but, for all that, they were less serious than crimes aimed directly at the state or the individual. The set penalties could

9 Inger 2011, p. 210.

10 Juridiskt Arkif, volume 9, 1838-39, pp. 14, 17. Quotation on p. 14. In 1841 , the punishment of breaking on the wheel and aggravated capital punishments (chopping off one hand, displaying the dead body in public after execution, burning at the stake) were abolished, as was sitting in the stocks. In 1855, birching and public penance were also abolished. Inger 2011, p. 298.

11 Kongl. Maj:ts och Rikets Svea Hof-rätts Underdåniga Utlåtande, pp. 5, 9f; Häthén 1990, pp. 159, 198, $212 \mathrm{f}$.

12 Inger 2011, pp. $299 \mathrm{f}$. 
therefore be reduced. ${ }^{13}$ The Penal Act of 1864 abolished the death penalty for incest, replacing it with hard labour.

As was pointed out above, several incest prohibitions had been questioned in repeated parliamentary debates during the first decades of the nineteenth century. The relationship categories that had caused the most heated debates were the second collateral consanguinity degree (cousin), the first collateral affinity degree (wife's sister, brother's widow), the diagonal affinity degree (wife's niece), and the second affinity degree (wife's stepmother, stepson's widow). Following the royal regulation of 1845 , the prohibition against cousin marriages had been abolished, but other prohibitions remained in force. As the Penal Act of 1864 became valid, the new reduced penalties were introduced, and incestuous relationships were assessed and punished as shown in Table 11.

As can be seen from the table, the maximum penalty imposed for incest crimes was reduced from the death penalty to hard labour for eight to ten years. In practice, though, the death penalty had all but ceased to be applied long before this legislative change.

The Act of 1864 introduced a differentiation between adults and children for the first time, the maximum penalty imposed for minors being set at roughly half of that for an adult. Children under the age of fifteen were completely exempted from punishment. For the first time, an adult party's guilt and responsibility for a crime was separated from that of a minor. In spite of this, legislators assumed that incest between parents and children was a question of abuse of parental authority through seduction rather than through violent assault. In cases where the younger party had not been subjected to physical violence, it was assumed that the child had not suffered any actual harm. ${ }^{14}$ If an incestuous relationship had begun before the child was fifteen years old but was discovered only after she (or he) had reached the age of criminal responsibility, the younger party could also be convicted of the crime. ${ }^{15}$

In addition, the law involved an increased differentiation between consanguinity and affinity incest. The first differentiation in this direction had been introduced in connection with the Civil Code of 1734, when capital punishment for affinity incest in collateral degrees (wife's sister, brother's widow) had been replaced by a

13 See the summary of the 1832 legislative proposal in SOU 1935:68, p. 39; Häthén 1990, pp. 198f.

14 Bergenheim 1998, p. 136.

15 Lindstedt Cronberg 2002, pp. 130f; Bergenheim 1998, p. 132. 
Table 11. Incest prohibitions and punishments in accordance with the Penal Act of 1864

\begin{tabular}{|c|c|c|c|}
\hline $\begin{array}{l}\text { Family } \\
\text { relationship }\end{array}$ & Closeness & Relationship, a man and his ... & Punishment \\
\hline \multirow[t]{3}{*}{ Consanguinity } & First/second lineal degree & $\begin{array}{l}\text { mother, grandmother, daughter, } \\
\text { granddaughter }\end{array}$ & $\begin{array}{l}\text { Adult: Hard labour } 8-10 \text { years } \\
\text { Child: Hard labour } 6 \text { months }-4 \text { years }\end{array}$ \\
\hline & First collateral degree & sister & Hard labour $2-6$ years \\
\hline & Diagonally & $\begin{array}{l}\text { aunt, grandfather's sister } \\
\text { niece }\end{array}$ & Hard labour max 2 years \\
\hline \multirow[t]{4}{*}{ Affinity } & First/second lineal degree & $\begin{array}{l}\text { stepmother, mother-in-law, grandfather's } \\
\text { widow, stepdaughter, daughter-in-law }\end{array}$ & $\begin{array}{l}\text { Adult: Hard labour } 6 \text { months-4 years } \\
\text { Child: Gaol, max } 6 \text { months, or hard } \\
\text { labour max } 2 \text { years }\end{array}$ \\
\hline & First collateral degree & wife's sister, brother's wife & Fine \\
\hline & Diagonally & $\begin{array}{l}\text { uncle's widow, wife's niece, nephew's } \\
\text { widow, grandmother's brother's } \\
\text { widow }\end{array}$ & Fine \\
\hline & Second degree & $\begin{array}{l}\text { wife's stepmother, wife's grandmother, } \\
\text { stepson's widow, grandfather's widow }\end{array}$ & Fine \\
\hline
\end{tabular}




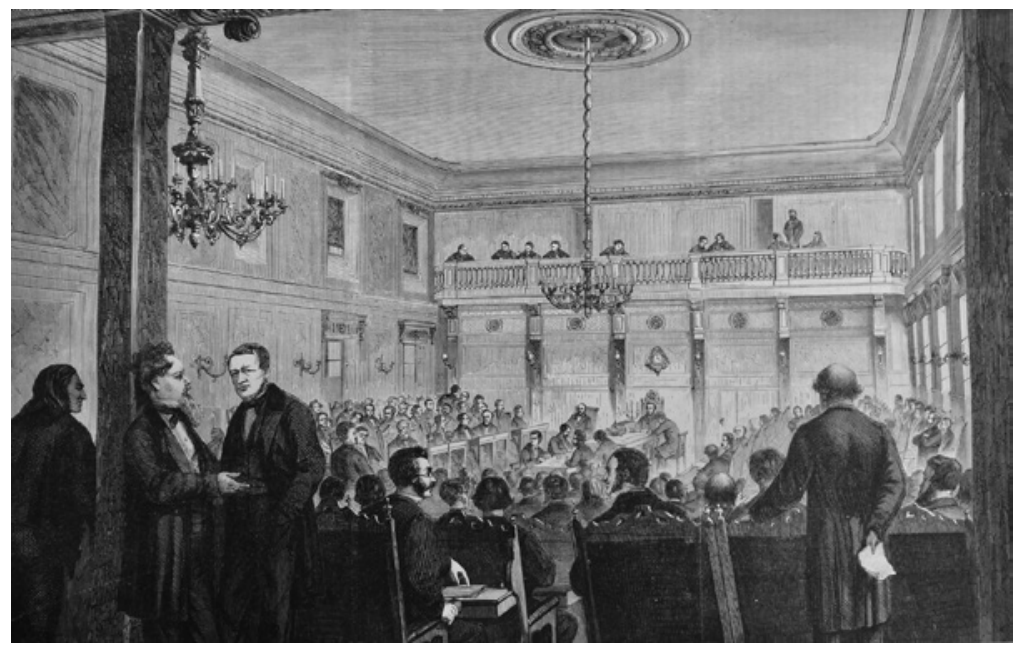

15 Negotiations in the Second Chamber of the Riksdag.

prison sentence, while consanguinity incest in collateral degrees (sister) continued to be punishable by death. The Act of 1864 brought differentiation with regard to the range of punishments in lineal degrees, in that biological relatives who violated the incest prohibition were sentenced to nearly twice as long a period of hard labour as people who were related through affinity relationships.

Even after the change in the law, new bills continued to be submitted to the Riksdag, with renewed demands for the liberalisation of additional relationship categories. ${ }^{16}$ The initiators of the bills sat in the Second Chamber, which was dominated by farmers, but these proposals also had the support of members of the First Chamber, who were mainly higher officials, estate owners, and factory owners. ${ }^{17}$ On a couple of occasions, the king put a stop to a legislative change; but in 1872 political pressure resulted in the abolition of the affinity prohibition in the first collateral degree, the diagonal degree, and the second degree. ${ }^{18}$

16 Bills were submitted in 1868,1870 , and 1871.

17 On the division of the Chambers, see Inger 2011, p. 209. On the attitudes of each Chamber, see Lagutskottets Utlatande $n r$ 47, 1868, pp. 8f; F.K. 1868, volume 4, pp. 569f; A.K. 1868, volume 4, p. 469.

18 K.F. 1872, 24 May. Example of a previous rejection of a bill by the king: Kunglig Skrivelse $n r$ 7, 1869, pp. 1f. 
Contributions to the debate that led up to the legislative change described the older law as obsolete. In a report of 5 May 1868, the parliamentary committee on legislation noted that there was no longer any 'valid reason' for keeping the prohibitions against horizontal and diagonal affinity relationships. Applications for permission to marry submitted by people in these relationship degrees were never rejected, and the prohibitions appeared a 'purposeless formality' that was 'an obstacle to everyone and expensive to those of small means'. ${ }^{19}$ Ola Månsson, a representative of the Second Chamber and the initiator of a couple of bills, argued that it 'frequently' happened that 'on the death of either spouse, the survivor wish[ed] to enter into marriage with one of the siblings of the deceased' ${ }^{20}$ Count Erik Sparre of the First Chamber claimed that 'the general opinion in the country' was in favour of such marriages. ${ }^{21} \mathrm{~A}$ similar opinion was expressed by Count Oscar Mörner when he claimed that there was a 'fairly general desire' for the legislation to be changed. ${ }^{22}$ Even though individual members still expressed their doubts about a potential liberalisation, they were in a clear minority. When the Speaker of the Second Chamber, after the conclusion of a discussion in the parliamentary session of 1868, asked if the proposal for liberalisation should be supported, 'there were many cries of yea along with a very occasional nay'. ${ }^{23}$

A large majority of the Riksdag members from both chambers hence described what they perceived to be changed norms in society. Marriages between people related through matrimony were no longer thought to give offence; on the contrary, they appeared to be popular and even desirable.

\section{Applications for dispensation}

The Riksdag members' contention that collateral affinity relationships were generally accepted in society is confirmed by other source material. The number of applications for dispensation from people

19 Lagutskottets Utlàtande $n r$ 47, 1868. See also Lagutskottets Utlåtande $n r$ 16, 1859/60, p. 17.

20 Motion, nr 302 (Bill no. 302), 1868, pp. 3f.

21 F.K. 1868, volume 4, p. 269.

22 F.K. 1871, volume 2, pp. 31f. Here Mörner bowed to the 'general desire', in spite of his claim that he himself sympathised with those who wanted the prohibitions to be retained.

23 F.K. 1868, volume 4, p. 270. 


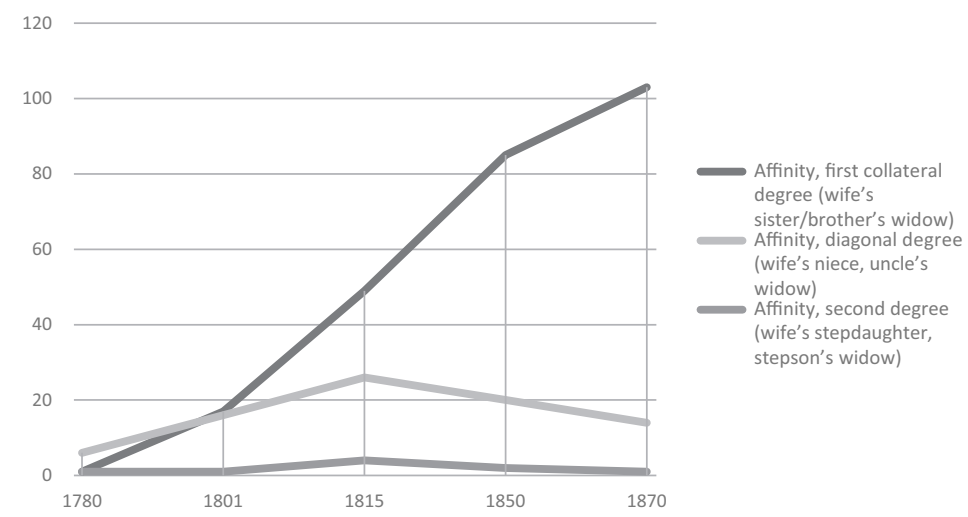

Graph 2. Applications for dispensation directed to the Judiciary Inspection, 1780-1870, selected categories.

Source: The diaries of the Judiciary Inspection for the year in question.

related by marriage increased continuously during the whole of the nineteenth century. The applications were received by the Judiciary Inspection and routinely approved. ${ }^{24}$

Graph 2 shows the number of applications for dispensation for affinity relationships that reached the Judiciary Inspection during the century preceding the legislative change in 1872. Lineal affinity relationships were not the subject of a liberalisation debate during the nineteenth century and are hence not included in these statistics.

As the table shows, it was only the category of first collateral affinity degree (wife's sister, brother's widow) that stood out with a continuous and significant increase in the number of applications during the whole of the period. Nevertheless, the other affinity categories were lumped together with this one in the debate. The relationships were assessed in similar ways, and when one category was liberalised, the other categories followed suit.

As in the rest of Europe, marriages between related couples hence continued to increase in popularity in Sweden throughout the nineteenth century. Cousin marriages, liberalised as early as 1845 ,

24 On 21 November 1850, applications for marriage from five couples were approved simultaneously. JR, R, 1850, 21 November. On 11 February 1870, permission to marry was granted for five couples; and on 25 February of the same year, three more couples received approval. JR, K, 1870, 11 February; JR, K, 1870, 25 February. 
are not included in these statistics either, but these marriage constellations also continued to increase in the same way. ${ }^{25}$ The popularity of marriages between relatives culminated just before the First World War. $^{26}$ As was discussed above, this development may in part be linked to changed economic and cultural conditions in society. Marriages within the family were still particularly common in noble circles, but several studies describe a stronger tendency also to accept strategic marriage alliances within the family in the burgeoning bourgeoisie of the nineteenth century. ${ }^{27}$ British social anthropologist Adam Kuper has described how some of the most successful middleclass families in Britain created large networks of family alliances during the nineteenth century with the help of systematic cousin marriages. These family-based networks provided advantages for the group in question in the general competition for capital and offices. Similar systems were used by burghers in several European countries during the early nineteenth century. ${ }^{28}$

With respect to Sweden, historian Anita Göransson has shown that similar strategies were used by Swedish merchants and factory owners during the same period. Within these groups, cousin marriages were strikingly common, as were other matrimonial family alliances, for instance two brothers from one family marrying two sisters from another or, alternatively, a man marrying his deceased wife's sister. Göransson notes that the likely purpose was to keep property together within the family in order to remain strong in the competition with the outside world. ${ }^{29}$

Even though the upper social groups are over-represented in the dispensational material in relation to the composition of the population, economic motivation for the formation of marriages affected lower social groups as well. A study of marriage patterns in northeastern Sweden established that there was a preponderance of marriages between relatives in the peasant-proprietor class in comparison to unpropertied groups. ${ }^{30}$ In addition, many applicants are entitled 'leaseholder' or 'artisan' in the dispensational material.

25 Egerbladh and Bittles 2011, pp. 413, 418.

26 Alström 1958, p. 300. Sabean 1998, p. 436.

27 In 1800, the proportion of cousin marriages within the nobility was 6 to $13 \%$, in 18505 to $20 \%$. The corresponding number for the entire population at the same time was $1-1.5 \%$. Alström 1958, p. 336.

28 Kuper 2009, pp. 24-8, 243. Sabean 1998, pp. 428-48; Sabean, Teuscher, and Mathieu 2007b, pp. 187f; Johnson 2011.

29 Göransson 1990, pp. 525f, 540.

30 Egerbladh and Bittles 2011, pp. 413, 419. 


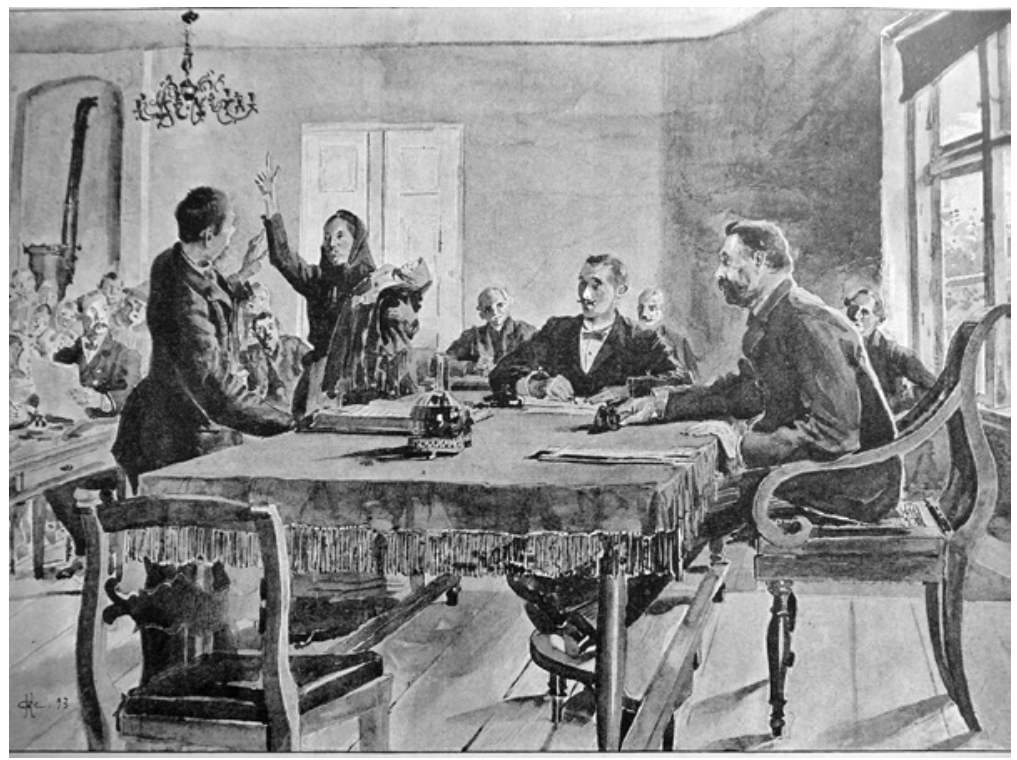

16 In the nineteenth century, the hundred court was still led by the hundred-court judge and the co-opted lay judges.

Consequently, this phenomenon was not confined to specific social strata but more or less generally accepted.

\section{Criminal cases}

In the mid-1800s, approximately as many incest crimes were heard in Swedish courts as at the beginning of the century, and the distribution of the different relationship categories was similar. ${ }^{31}$ In the material from the mid-nineteenth century, however, greater tolerance of relationships between relatives is discernible. At the turn of the century in 1800 , the regulatory framework had been challenged by couples related through marriage behaving towards each other in what was felt to be a much too affectionate manner in public contexts, as was illustrated by the cases described in the previous chapter. But this had mostly amounted to an indirect questioning of the incest prohibitions, because the people in question often lived in

31 This statement is based on the material of the Göta Court of Appeal. For more detailed criminal statistics, see Appendix Table 3. 
the same household in a relationship that was superficially legitimate. People who lived in the same family and household defended their conduct by claiming that showing affection and tenderness within the family was a desirable kind of behaviour without admitting that their physical relations transgressed a moral boundary. There are also examples where a man and a woman lived together under the pretext of her being his housekeeper. ${ }^{32}$ There was thus no question of an open challenge to the norms at this time.

Fifty years later, in the middle of the nineteenth century, the official norms were challenged in a more obvious way. At this point in time, a man and a woman might live openly together as a loving couple, even after having been warned that their relationship was impermissible because they were related. When summoned to a judicial inquiry, such a couple might ignore the summons and quite simply fail to appear at the hearing. These patent challenges to the official legislation were particularly common when horizontal affinity relationships (wife's sister, brother's widow) were at issue. Anders Larsson Röding was, for instance, prosecuted for fornication with his deceased wife's two sisters, with one of whom he had formed a household and also wanted to marry. ${ }^{33}$ Mårten Persson and his deceased brother's widow moved in together and had children without having been granted official permission to marry by the Crown. ${ }^{34}$ Nils Erik Fagerström and his wife's sister Eva Sofia Olsdotter agreed to marry, moved in together, and lived as a married couple. When summoned to the local court, they failed to appear until the prosecutor had them picked up. ${ }^{35}$ Widower Anders Olofsson wanted to marry his niece Anna Cajsa Johansdotter and went to the local clergyman to have the banns published. He was then told that their relationship was prohibited; but as neither Anders nor Anna was able to see 'the criminal nature' of their relationship, they nevertheless moved in together and lived as a married couple. Only when Anna became pregnant and bore an illegitimate child did the vicar report them to the county sheriff, who then prosecuted them. ${ }^{36}$

32 GHA, BIIA:98, 1785, no. 43; Hanekind hundred, AIa:34, 1784, 10 February, no. 2.

33 GHA, BIIA:318, 1851 no. 128; Stranda hundred, AIa:132, 1851, 24 September, no. 239.

34 GHA, BIIb:21, 1841, 5 November, no. 159.

35 GHA, BIIA:342, 1855, 26 September, no. 53; GHA, EVAC:1235, 1855 no. 53.

36 GHA, BIIA:293, 1845, 8 April, no. 37. 
As in earlier periods, pregnancy in particular often brought matters to a head, but in some cases not even an illegitimate child led to any immediate reaction from the people around the couple in question. Börje Larsson and his brother's widow Anna Jönsdotter moved in together and had a child with the explicit intention of getting married. They were not prosecuted for incest by the county sheriff until the child was three years old. ${ }^{37}$ Johannes Holm and his brother's widow Maja Lisa Petersdotter also formed a household, stating their intention to get married. When Maja Lisa became pregnant two years later, Johannes tried to have the banns published but was then told that they had to apply for a dispensation from the king in order to be allowed to marry. They thought this was too expensive and refrained from making the application, but continued to live together. When the couple finally ended up in court, their child was four years old. ${ }^{38}$

The decades around 1850 hence witnessed a more pronounced resistance towards certain types of incest prohibitions. Couples lived openly together in what the law defined as incestuous relationships for several years without anybody intervening, having children and planning a future together as husband and wife. In all these cases, the people involved displayed a striking lack of respect for and indifference to - or, alternatively, ignorance of - the applicable rules. By their actions, they rejected the official definition of their relationship as deviant or immoral. To be sure, they also challenged the norm that sexual relations should only occur within marriage; but in this respect they often attempted to achieve full legitimacy by expressing - in writing or orally - their desire to get married. These people thus seem to have had a certain amount of respect for the legitimacy of the marriage norm.

Two tendencies that may be discerned in the court material from the turn of the century in 1800 had been reinforced by midcentury. First, there was a tendency on the part of the authorities to reduce the punishment for couples who were found guilty of the crime of incest if their relationship appeared to be voluntary. In six out of nine cases where the prosecuted couple had violated the affinity prohibition in the first collateral degree, the punishment was reduced from twenty-eight to twenty-four days in prison. The common denominator of these cases was that the relationships were described as voluntary, or, alternatively, that the prosecuted

37 GHA, BIIA: 279, 1841, 11 October, no. 47.

38 GHA, EVAC:937, 1840, no. 27. 
individuals said that they wished to be allowed to marry. ${ }^{39}$ Even the full siblings Johannes Heberg and Anna Svensdotter had, to all appearances, a voluntary sexual relationship. They had been separated as children and had grown up apart. When they met as adults (she at the age of eighteen, he at the age of twenty-eight) they began a sexual relationship. They lived together for two years before they were prosecuted because of an illegitimate child. Before the court they confessed their crime, which was also confirmed by several witnesses. The witnesses described theirs as an 'unusually affectionate relationship'. They were to said to have 'sought solitude together' and had been seen lying together in the same bed on repeated occasions. According to one witness, they behaved 'as man and wife or as people betrothed'. Another witness based a suspicion of illicit relations on the mutual 'love' shown by the couple. The suspicions were confirmed later when the witness, peeping through a crack in the wall, watched them having 'carnal congress' ${ }^{40}$ Johannes and Anna were found guilty of incest and were sentenced to death, but had their sentences reduced to imprisonment according to the then current practice. But although the crime of incest in this case had been fully proven by the couple's own confessions and by the testimony of several others, and even though the relationship was between two biological siblings, the couple was not sentenced to the maximum prison sentence of twenty-eight days but only to twenty days in gaol. ${ }^{41}$ The reprieve was merely justified with the phrase 'on account of particular circumstances'. ${ }^{42}$ In my view, though, it is highly likely that this expression referred to the voluntary aspect of the couple's relationship, and that it was this circumstance that determined the more lenient sentence. The authorities were quite

39 GHA, BIIA:342, 1855, no. 53; GHA, BIIA:273, 1840, no. 27; GHA, BIIA:279, 1841, no. 47; GHA, BIIA:275, 1840, no. 29; GHA, BIIA:318, 1850, no. 98; HSoB, BIIb:21, 1841, no. 159.

40 GHA, BIIA:292, 1844, no. 93.

41 In the middle of the nineteenth century, hard labour was more or less routinely imposed in addition to gaol sentences for the most aggravated offences. Johannes and Anna were sentenced to five years of hard labour each after having served their gaol sentences. They were also threatened with flogging and birching if they resided in the same location in future. GHA, EIAC:22, 1845 , p. 13 . See also a case where a voluntary relationship between a man and his niece was punished by a mere sixteen days in prison and two years of hard labour. GHA, BIIA:293, 1845, no. 37; GHA, EIAC:22, 1845, p. 28.

42 GHA, EIAC:22, 1845, p. 13. 
simply more tolerant of voluntary incestuous relationships than before.

As was observed above, reactions in local communities had been affected by how individual relationships functioned even during the most theocratic period in the past. If a relationship was perceived to be voluntary, there was a greater propensity to support and protect those who were prosecuted for incest, regardless of how close the family relationship between the prosecuted individuals was. In the middle of the nineteenth century, these circumstances also influenced the assessment of the authorities and thus also the final sentences. Mutuality had to all appearances gone from only influencing the closest relatives and friends of the accused into being recognised by the authorities as a mitigating circumstance which could justify reducing the punishment. This change may also be described as an informal norm becoming officially accepted in society.

The second tendency that becomes visible in the criminal cases of the middle of the nineteenth century is the accused parties' readiness to deny the charge even when there were extremely compromising circumstances. The case of Jakob Larsson (forty-four years old) and his niece Greta Andersdotter (twenty-nine years old) may be quoted as an example. They were accused of incest in 1841. Greta had kept house for Jakob for nine years, but in reality they had wanted to get married. About a year earlier, Jakob had urgently asked the local judge to write an application for marriage for them, a plea with which the judge had reluctantly complied. The couple's application was rejected, though, and when Greta later became pregnant they were prosecuted for incest by the county sheriff. Both Jakob and Greta stubbornly denied the accusation and were acquitted because of a lack of evidence. ${ }^{43}$ Other couples who denied the charge were acquitted, too. ${ }^{44}$ Of course, there is a theoretical possibility that the couples who denied the charges were not in fact guilty, but

43 GHA, EVAC:971, 1841, no. 47; GHA, BIIA:280, no. 43.

44 See, e.g., GHA, BIIA:293, 1845 no. 103; GHA, EVAC:1041, 1845, no. 103; HSoB, BIIb:31, 1851, no. 6. Another, more depressing, example is Kjerstin Mattisdotter, who claimed before her mother and sundry witnesses that her stepfather had raped her. However, at trial both of them denied the crime and were acquitted, 'yet her entire being betrayed great dejection'. Witnesses stated that the girl had been urged not to lay the blame on her stepfather in order to avoid making them both 'unhappy'. Medelstad hundred, AIa:133, 1840, 13 February, no. 429; 29 February, no. 445; 11 May, no. 249; 5 June, no. 462; HSoB, BIIb:20, 1840 no. 123. 
it is not reasonable to assume that all of them were innocent. Rather, the denials form part of a new pattern of behaviour in the accused.

The fact that more people chose to deny committing the crime, in spite of all the circumstances that indicated their guilt, may - as was the case before - be explained by it being easier to escape conviction because the evidential requirements had become more stringent. But considering that the challenges to the regulatory framework were more overt, it is also likely that the official definition of the relationship as a criminal act was rejected by those who violated the rules. This was probably the case with several couples who were related in collateral affinity degrees, because these couples chose to live together openly in direct violation of the applicable rules. In criminal cases concerning other relationship categories, the obstinate denials may have been occasioned by the prosecuted individuals questioning the reasonableness of the penal consequences.

When Börje Bengtsson was prosecuted for committing incest with his daughter Inger, he chose to stubbornly deny the accusation before the court. Inger, who was Börje's illegitimate daughter, had grown up with her mother and moved to her father aged seventeen, whereupon father and daughter appear to have developed a liking for each other. According to testimony, Börje - in a state of 'intoxication' - admitted to being the father of both Inger and her illegitimate child. But in court he denied all culpability. Before a witness, he apparently said that he did not want to confess because he risked ending up in 'the hands of the executioner'. When the members of the hundred court urged him to confess his crime, he reportedly answered that he "would not confess before those who wished to commit murder'. ${ }^{45}$

Börje was thus well aware of the legal consequences of his crime, but he did not acknowledge the right of the authorities to put him to death. He described the anticipated punishment as a murder - an unjust killing - and it was obviously the penalty to which Börje objected. By way of various statements, he indirectly admitted that he, too, understood the relationship as illicit. Before one witness, he stated that he had 'found himself sorely tempted', and before

45 At the beginning of the trial, Inger accused her father of having forced her to have sex. However, the 120-page records give a clear impression that the relationship was completely voluntary and that Inger's statement was an attempt to minimise her own guilt. She later retracted her confession, and the couple were acquitted from a lack of evidence. GHA, EVAC:1003, 1843, no. 14; GHA, BIIA:286, 1843, no. 14. 
another acquaintance he said that he believed that a 'confession before God was enough to receive absolution'. ${ }^{46}$ Börje thus did not protest against the definition of the relationship as sinful and prohibited, but against its penal consequences.

Taken together, the tendency for more couples to deny committing a crime and the tendency for the punishment to be reduced when the relationship appeared to be voluntary confirm that the crime of incest had acquired a changed status in society. The link between incest and morality norms appears even more patent than it did at the turn of the century in 1800 .

Any change must of course also be put in relation to the changed attitudes in society to other moral crimes during the same period. With respect to how the accused acted before the court, Marie Lindstedt Cronberg describes a very similar development regarding 'ordinary' sexual crimes in Sweden from 1680 to 1880. Up until 1778, both men and women usually confessed their crimes with an almost 'naive sincerity'. In 1778, the so-called infanticide proclamation was announced, making it possible for women to bear illegitimate children without naming the father. After this turning-point, women increasingly often claimed to have been bedded by an 'unknown man'; but in cases where the woman named a man as the father of her child, he usually denied the accusation and escaped punishment. Lindstedt Cronberg connects the change in behaviour to general social developments. Attitudes to sexual crimes had become more lenient, which made it easier to deny committing them. ${ }^{47}$ The change is illustrated by the fact that the number of illegitimate births increased continuously during the nineteenth century while the general frequency of marriage tended downwards. A changed attitude to sexual crimes also comes out in the legislation in that the regulatory framework for extramarital sexuality was made more lenient in the course of the nineteenth century. These legislative changes led to a gradual reduction of the number of sexual crimes

46 In total, around fifty witnesses were heard. Six claimed not to know anything. Approximately thirty witnesses described compromising circumstances in the form of suspicious statements or acts by the accused. Around twenty witnesses claimed that either Börje or Inger had confessed their relationship to them. Two men claimed to have been offered economic compensation for admitting to being the father of Inger's child and marrying her. GHA, EVAC:1003, 1843, no. 14.

47 Lindstedt Cronberg 1997, pp. 73f, 142-50, quotes on pp. 143, 145. 
in Swedish courts, and around 1870 they had all but ceased to appear. $^{48}$

Both the legislative changes and the behaviour of the accused in court indicate a cultural shift with respect to attitudes to sexual offences in general, and there are strong indications to the effect that attitudes to some incestuous relationships adhered to this trend. ${ }^{49}$ This might account for the general reduction in the number of incest crimes that has been noted between the turn of the century in 1700 and the turn of the century in 1800 . The crimes were simply increasingly rarely reported. In some incest cases, it is difficult to determine whether the family relationship played a role at all; the following case supplies an example.

In 1843, Nils Larsson accused his brother-in-law, former hussar Sven Wall, of having made Nils's daughter Anna pregnant. Nils demanded that Sven should pay for the child's upkeep. But Anna herself, who worked as a servant in Sven's household, absolved Sven from responsibly and claimed that it was a pedlar who was the father of her baby. A witness described that he had seen Sven and Anna lie together in bed at night, and that the relationship between them in general was friendly and intimate; but the same witness swore that he had not seen any direct 'illicit congress' at the time of conception. Anna's father for his part was entirely convinced of how things had happened, and he expressed his view of the case in a formal letter to the court:

Because of the seductive actions of Sven Wall, my daughter has violated both secular and divine law and thus caused herself to be hated and reviled among the citizens in [our] community. And more than that, she has laid a heavy burden on us, her aged parents who are approaching our graves, hastening [our] descent into the grave with her $[\ldots]$ way of life and great disobedience. Not only did she,

48 Nilsson 2011, p. 76; Carlsson 1977, p. 14. In 1810, the secular punishment for fornication was abolished for women at the first and second violation. After 1864, public prosecution was no longer brought for sexual offences. However, fornication was not decriminalised until 1918 and adultery not until 1937. Inger 2011, pp. 300f, 373.

49 Examples of incest cases where a man, in a manner resembling that described by Lindstedt Cronberg, was identified as the father of a child by the woman but denied committing a crime can be found in GHA, EVAC:1066, 1846, no. 31; GHA, BIIA:298, 1846, no. 30; GHA, BIIA:322, 1851, no. 93; GHA, EVAC:1083, 1847, no. 105; GHA, BIIA:304, 1847, no. 105; GHA, BIIA:323, 1851, no. 135. 
in opposition to the admonitions given by us, commit adultery with Sven Wall, but she eventually [made] her father a liar both in writing and in speech [by] brazenly absolving Sven Wall before the lawful hundred court from having made her with the child whose upkeep is the subject of the present matter. ${ }^{50}$

In view of several compromising circumstances, the suspicion that the prosecuted individuals were guilty of the crime of which they were accused seems natural; but regardless of whether Sven was the father of Anna's child or not, Anna's father was sure of his brother-in-law's guilt. It is, however, uncertain whether it was the family relationship in itself which angered him most. Nowhere did he emphasise that it was the family relationship that was the main cause of his indignation. He referred to the crime as 'adultery' instead of adultery or fornication in a probibited degree, which was a more common description of incest crimes. He was horrified that his daughter had lost her honour and the respect of the community through her actions, and that her child was not properly supported. He placed the guilt for his daughter's situation on Sven, who had lured the girl to her ruin with 'seductive actions'. ${ }^{51}$

Would Nils have reacted differently if there had been no family relationship between Anna and Sven? If the act had 'only' violated the norm that sexual activity should take place within marriage? There is no certain answer to this question, but my impression is that at this time, incest crimes in the more distant degrees - as was the case in this example (diagonal affinity degree) - were often handled without any particular emphasis being placed on the family relationship. ${ }^{52}$ Consequently, it is hard to assess exactly which norm was under negotiation - extramarital sexuality, or extramarital sexuality in the probibited degrees.

Both Riksdag records and applications for dispensation, as well as the criminal-case material, show that social attitudes to incest crimes continued to move in the direction of increasing tolerance. Affinity relationships in collateral and diagonal degrees were largely

50 GHA, EVAC:1013, 1843, no. 111.

51 GHA, EVAC:1013, 1843, no. 111.

52 In another example, the family relationship between the man and the woman was treated as only one offence among several petty crimes. Apart from the affinity crime, the man was also accused of 1) having moved into the poorhouse without permission, 2) stealing a hat, 3) breaking the Sabbath, and 4) three 'shovings'. Västbo hundred, AIa:202, 1849, no. 173, 19 June; 20 June, no. 197; GHA, BIIA:314, 1849, no. 100. 


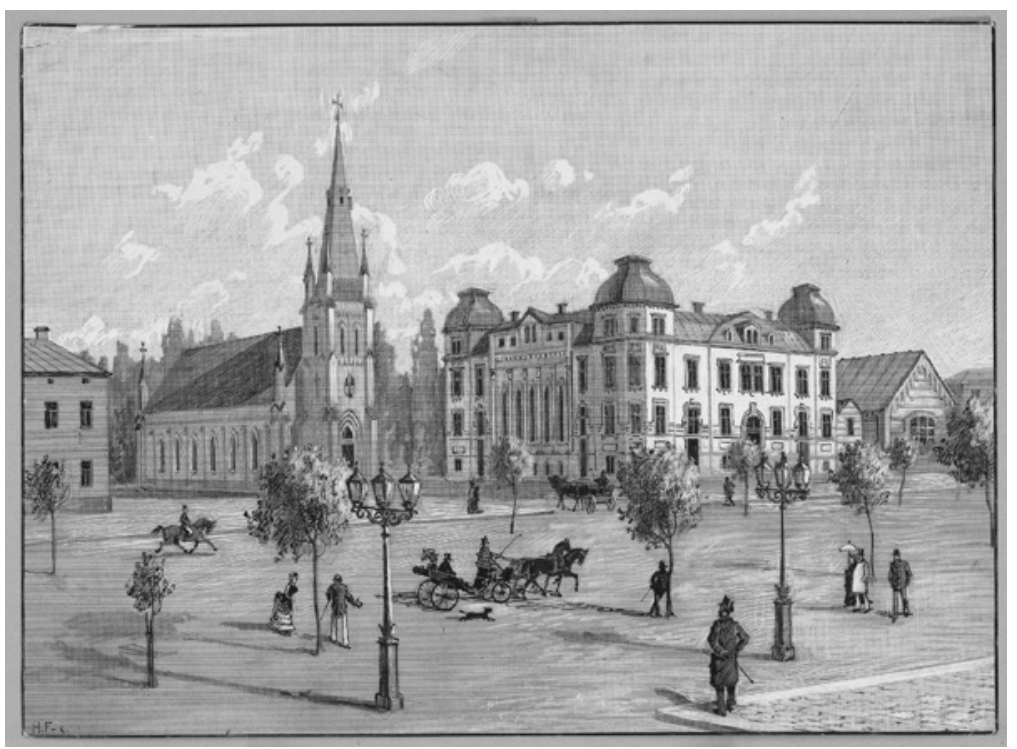

17 In connection with the Industrial Revolution the population in Swedish cities increased greatly, creating a need for altered urban environments. During the late nineteenth century, many old city blocks were torn down and replaced with large, modern stone buildings. This picture shows the Swedish capital, Stockholm, at the end of the nineteenth century.

treated as any other moral crime without the family relationship being foregrounded as an aggravating circumstance. The importance of the family relationship for the assessment of the crime thus seems to have vanished, or at least to have been significantly reduced. When the prohibitions against marriage in collateral and diagonal affinity degrees were abolished in 1872 , it was thus an adaptation to this new norm. Once more, then, the legislative changes functioned as a codification of new ideas that had emerged in Swedish society during the first half of the nineteenth century.

\section{The turn-of-the-century world of ideas, 1872-1940}

Around the turn of the century in 1900, science had begun to replace religion as a normative basis for ethics and morals. As religion was increasingly privatised, the general social influence of the clergy 
lessened, doctors and scientists stepping up instead as obvious new spokesmen for the good of society. Family life and sexuality became an issue for medical experts.

Through Charles Darwin's theory of evolution the animal origins of the human race were made visible, which contributed to the increasing tendency of science to see sexual drives as natural instincts. ${ }^{53}$ True, sexuality had also been perceived as natural according to Lutheran ideology, but sexual desire should be channelled into the marriage and the system of human reproduction established by God. During the second half of the nineteenth century, doctors began to argue that sexuality affected the well-being of the individual. Sexual satisfaction became a health-related issue. ${ }^{54}$ This development has been described as a separation of romantic love and sexual desire, sexual desire being considered an innate, seething power in the human being. Passions were no longer seen as harmful animal lusts that had to be controlled and suppressed, but as a positive natural force for everybody to embrace. If the natural drives were suppressed, this might lead to sickness or depression. In addition, men's sexual needs came to be regarded as stronger than those of women; consequently, it was considered particularly important that their needs be satisfied. It was feared that a repressed male sexuality could lead to 'unnatural' sexual acts, such as masturbation, rape, or incest. A man who did not have an outlet for his natural lusts was therefore seen as a potential threat to the chastity of virtuous women. At the same time, most men had to wait until their thirties before they could get married, because it was not until then that they had a steady income and could support a family. According to this line of reasoning, the average man hence constituted a potential danger to himself and to the women around him for ten to fifteen years before marriage provided him with a natural outlet for his desires. The solution to this dilemma was an established double standard, where extramarital sexuality was forbidden while stateregulated prostitution was introduced. Apart from certain delays and minor national variations, developments were similar in several European cities. ${ }^{55}$ The double standard was, however, criticised from

53 On the Origin of Species, where Darwin presented his theory, was published in 1859. On the link between race biology and Darwin's ideas, see Broberg and Tydén 1991, p. 11.

54 Lundquist 1982, p. 409; Ekenstam 1993, pp. 261, 263; Bergenheim 1998, p. 122.

55 With respect to Sweden, see Lennartsson 2001, pp. 95-101. Quotation on p. 95. Lennerhed 1994, Chapter 1. Tommy Lundquist provides a detailed 
several directions, which resulted in heated social debates in the decades before the turn of the century. This criticism led to a deregulation of prostitution in Great Britain and the Scandinavian countries, whereas control of prostitutes continued in France, Germany, and Italy. ${ }^{56}$

The Swedish debate on morality and prostitution that arose in the 1880s may be described as a fiercely ideological battle. In this morality debate, which later became very well known, the focus was on family life and marriage as an institution. Some people promoted new - and challenging, for their time - ideas about free love and the use of contraceptives. Others defended the importance of marriage and monogamy for the happiness of the individual while simultaneously arguing for women's equality with men. ${ }^{57}$ Although it was possible to live together without being married at this time, marriage was still considered the only legitimate way of cohabiting. ${ }^{58}$

The publication of the Darwinian theories of evolution not only contributed to shifts in views on sexuality, it also led to greater interest in the biological development of the human race. Once the first shocking insight that human beings might be descended from apes had settled, theories were formulated about the human civilising process. This development was described as a process of advancement, where people went from an originally primitive condition towards an increasing degree of civilisation and refinement. Animals were of course ranked as lower-standing creatures in relation to human beings, but human races were also divided according to how far they were considered to have progressed in the development of their civilisation. Unsurprisingly, white Westerners were put at the top of the evolutionary ladder, while groups that were defined as primitive tribes or aboriginal people from other parts of the world were placed further down the scale. The notion of the civilised white male

picture of the history of the regulation of prostitution in Sweden, from its introduction in the mid-nineteenth century to its abolition in 1918, in Lundquist 1982. For developments in Britain and Germany, see Walkowitz 1982 and Meyer-Renschhausen 1997. For a general overview of developments in Europe, see Blom 2012, pp. 25-32. For an overview of the debate in French and German forensic medicine, see Bergenheim 1998, pp. 122-31.

56 Blom 2012, p. 32.

57 Levin 1994, pp. 144-62.

58 The number of extramarital births had increased steadily in Sweden during the nineteenth century, and at the turn of the century in 1900 they made up approximately 15\%. Nilsson 2011, p. 76. 
helping other peoples to attain a similar degree of civilisation was, among other things, used to justify colonisation and imperialism. ${ }^{59}$

Ideas of race biology also spread to the social sciences, and soon eugenic terminology was being used to explain social differences in society. ${ }^{60}$ The argument for these social-Darwinist ideas may be summarised as follows: those who managed successfully in society did so because they had received strong and vigorous genes, whereas poor people and social outcasts had probably been equipped with more deficient genes in the game of hereditary biology. ${ }^{61}$ It was consequently believed that the development of the individual contained an element of biological determinism. On the heels of the ideas concerning the increasing degree of civilisation and refinement of the human race followed, as a logical consequence, the insight that this development could be reversed. The race might degenerate, or regress to an earlier stage of development. For the eugenic movement, it thus became an important goal to improve the human race by controlling procreation in the country. Similar ideas existed in several European countries, as well as in Russia, the United States, and China; but after Germany, Sweden may be said to be one of the countries where ideas on racial hygiene and positive and negative eugenics gained the strongest foothold, both scientifically and politically. ${ }^{62}$

\section{The marriage act of 1915}

In this eventful period of cultural and political turbulence, a review of the incest legislation took place. This time the Swedish law-drafting committee worked in close cooperation with the other Nordic countries, which resulted in a new Swedish marriage act in 1915 - the Act on the Celebration and Dissolution of Marriage. In the discussions that preceded the legislation, race-biological views were clearly expressed. New medical impediments to marriage were introduced, and the justification of the new law stated that its purpose was to protect 'future generations, in the interest of maintaining and improving the human race'. The desire was to 'both promote

59 Eriksson 1983, p. 125.

60 Tydén 2002, pp. 21-41. The Swedish debate contained parallel interpretations which emphasised the importance of social and cultural differences above that of racial differences. Tydén 2002, p. 22.

61 Eriksson 1983, p. 125.

62 Broberg and Tydén 1991, pp. 16-32. 
the marriage frequency in the best of our members and prevent the procreation of the inferior' in order to 'gain the most able offspring from marriages'. ${ }^{63}$

Around the turn of the century in 1900, health-related consequences for the human race were thus at the centre of the Swedish incest debate. Within medicine, it was assumed that the risk of a disease being transferred to the next generation increased if both parents carried the same predisposition for that disease. But there was no evidence of an increased risk of disease for children with closely related parents, unless there was a predisposition for disease in the family. This explains why the authorities came to display a great deal of interest in the health status of couples applying for dispensation and their families. ${ }^{64}$

In comparison to Danish and Norwegian legislation, the Swedish incest prohibitions were more restrictive in the sense that marriages between people in the diagonal consanguinity degree (aunt, niece) were completely forbidden. In Denmark and Norway, a dispensation was required for marriages between a man and his aunt; but there were no restrictions for marriages between a man and his niece. ${ }^{65}$ The dissimilar rules were seen to be problematic, though, in that people could travel across the border in order to get married, causing doubts about the validity of their marriage. The perception as to whether the marriage was valid or not determined whether any children had a right of inheritance after their parents. ${ }^{66}$ In order to reduce the risk of later disputes, some couples applied for foreign citizenship before travelling across the border to get married, whereupon they returned to Sweden as foreign citizens. ${ }^{67}$

In order to adapt the Swedish legislation to the regulatory framework of the other Nordic countries, Sweden introduced an opportunity to apply for dispensation for marriage in the diagonal consanguinity degree in connection with the new marriage act. But the explanatory remarks to this act emphasised that such applications

63 Lagberedningens förslag till revision av giftermålsbalken...I, p. 131. The same justification was emphasised in brief summaries of the legislation. Lag om äktenskapets ingående och upplösning, p. 32.

64 Lagberedningens förslag till revision av giftermålsbalken...I, p. 198.

65 In Germany similar marriages were also permitted. Nya äktenskapslagen med förklaringar, pp. $52 \mathrm{f}$.

66 See, e.g., Nytt juridiskt arkiv, afd. I., 1907 (dispute about inheritance), p. 82, or Nytt juridiskt arkiv, afd. I., 1883, p. 13 (attempt at ex-post legalisation of a marriage that took place abroad).

67 Lagberedningens förslag till revision av giftermålsbalken...I, pp. $199 \mathrm{f}$. 
would only be approved if the good health of the applicants and their families could be verified, or, alternatively, if the marriage was expected to be childless. With the Act of 1915, the regulations regarding kinship in affinity degrees also changed. Previously it had been the sexual act itself that bound two people together in a family relationship in affinity degrees; but from 1915 and onwards, it was instead the marriage that became the defining element for this family relationship. ${ }^{68}$ Among the affinity prohibitions only one remained, the lineal one (stepmother, stepdaughter, mother-in-law, daughterin-law). This was also the only impediment to marriage to be justified with moral instead of eugenic arguments. ${ }^{69}$

In line with the new eugenic ideas, all applications for dispensation for marriage were sent to the National Swedish Board of Health (Medicinalstyrelsen) for medical vetting before a decision on whether to approve or reject them was made. The Crown had the ultimate power to decide the outcome of these cases, but the recommendation of the National Swedish Board of Health was followed to almost $100 \% .{ }^{70}$ Consequently, the assessment of the dispensational cases had been moved to the medical profession, whose members were considered to represent objectivity and scientific knowledge, in line with the ideals of the time.

\section{Applications for dispensation}

The new marriage act led to a significant increase in applications for dispensation for marriages in diagonal consanguinity degrees (aunt, niece). During the five-year period preceding the introduction of the Act, there was no such application for dispensation. Between 1915 and 1920, sixty-four applications for dispensation were submitted to the Ministry of Justice, of which sixty-three came from couples who were related in precisely this way. ${ }^{71}$ Most of the applications

68 Lag om äktenskapets ingående och upplösning, p. 46.

69 Nya äktenskapslagen med förklaringar, p. 53.

70 In four out of sixty-four cases (approximately 6\%), the king chose to reject an application for dispensation in spite of the National Swedish Board of Health having established that no medical reasons created an impediment to the marriage. No documented argumentation clarifies why this happened in these four particular cases. See, e.g., JD, Cabinet-meeting document (konseljakt), R, 1917, 20 July, no. 23, Knut Westin, Gerda Lundgren; JD, K, 1917, 20 July, Knut Westin, Gerda Lundgren.

71 The Ministry of Justice received thirty-eight applications for dispensation for marriage between the years 1910 and 1914, but only one concerned 
were submitted in the same year as an amendment of the law came into force (1916) or the year thereafter, as can be seen in Table 12.

Several applications involved relationships where a man and a woman already lived and had children together. When the amendment of the law opened up new opportunities, they wanted to legalise their relationships; but because the relationships were, properly speaking, prohibited and punishable, their character is rarely made immediately apparent in the material.

Two couples applied for dispensation for marriage as early as 1915; that is, before the new marriage act had come into force. The applications of both couples were rejected, causing re-submission at a later date. In both cases, it is only the later application that makes it clear that the couple lived together and had had children. ${ }^{72}$ A third couple applied for permission to marry via a lawyer's office in 1916. The first official letter was brief and relatively impersonal; but because the National Swedish Board of Health asked for complementary information, the lawyer revealed that this couple, too, lived together and had had four children. He had deliberately omitted this information before, as 'their relationship was actually punishable before the amendment of the law'. ${ }^{73}$

The amendment of the law was thus immediately used when it became known, but it had not been preceded by any active pressures in the form of an increase in the number of applications for dispensation before it was adopted, as had happened in connection with previous legal amendments. After peaking during the initial years after the Act came into force, the number of applications for dispensation stabilised at less than ten per year for the entire country. It is hence not appropriate to speak of massive pressure or widespread popularity for these relationships either before or after the amendment of the law.

a too close family relationship. This case involved a family relationship in an affinity degree, not a consanguinity degree. SVAR's digital database for Cabinet-meeting documents in the Ministry of Justice (search term: 'äktenskap" hinder' ('marriage* impediment')).

72 JD, Cabinet-meeting document, 1915, 6 August, no. 29, Wilhelm Kaesen, Elisabeth Kaesen; JD, Cabinet-meeting document, 1917, 16 February, no. 39, Wilhelm Kaesen, Elisabeth Kaesen; JD, Cabinet-meeting document, 1915, 3 September, no. 37, Johan Skog, Emilia Skog; JD, Cabinet-meeting document, 1918, 31 July, no. 46, Johan Skog, Emilia Skog.

73 JD, Cabinet-meeting document, 1916, 17 November, no. 32, Anders Lindh, Anna Svensson. 
Table 12. Applications for dispensation directed to the Ministry of Justice, 1915-20

\begin{tabular}{|c|c|c|c|c|c|c|c|c|}
\hline Family relationship & Relationship & 1915 & 1916 & 1917 & 1918 & 1919 & 1920 & Total \\
\hline \multirow[t]{5}{*}{ Consanguinity, diagonally } & niece & 2 & 14 & 11 & 1 & 6 & 4 & 38 \\
\hline & aunt & & 2 & & 1 & 1 & & 4 \\
\hline & half-niece & 1 & 5 & 4 & 5 & & 1 & 16 \\
\hline & half-aunt & & 3 & & & & 2 & 5 \\
\hline & Sum total, consanguinity & 3 & 24 & 15 & 7 & 7 & 7 & 63 \\
\hline \multirow[t]{2}{*}{ Affinity, first lineal degree } & stepdaughter & & & & & & 1 & 1 \\
\hline & Sum total, affinity & & & & & & 1 & 1 \\
\hline Total & & 3 & 24 & 15 & 7 & 7 & 8 & 64 \\
\hline
\end{tabular}

Source: SVAR's digital database for Cabinet meeting documents in the Ministry of Justice. Search terms: 'äktenskap* hinder' ('marriage" impediment'). 


\section{A mild case of varicose veins and flatfoot}

The importance of contemporary eugenic ideas is clearly reflected in the formulation of the applications for dispensation. In new, standardised forms, the applicants had to answer questions about their health and family relationships. They were obliged to undergo a medical examination and be declared free of 'congenital deformities and physical and psychological disorders' by a practising physician who had 'knowledge' of the applicants' family relationships. At least two credible witnesses who knew the families of the applicants well had to certify that the applicants were not tainted by hereditary disease, such as 'mental disorder, mental deficiency, falling sickness, chronic alcoholism' or 'suicide'. In addition, the family relationship of the applicants relative to each other, as well as the health status of the families of each of them, should be certified by the clergyman on duty on a third form. ${ }^{74}$

The application documents were thus increasingly dominated by detailed descriptions of the applicants' physical health status. One person was said to have a 'healthy appearance and a good physique'. This person lacked any signs of 'contagious disease' or other 'predisposition for disease'. ${ }^{75}$ After conducting an examination of housekeeper Anna Westerberg, district physician Herman Melén certified that she was 'healthy and free [from] detectable predispositions for disease and had a normal physique without any deformities'. ${ }^{76}$ Olga Hagström was described by her doctor as 'healthy and strong but pregnant', and Amanda Wretholm was said to be 'healthy and in particular free from nervousness and nervous disorders'. ${ }^{77}$

Whenever a physician found physical weaknesses in the applicant this was stated, regardless of whether or not these weaknesses were included in the abovementioned liabilities. For example, Carl Carlsson's physician described him as 'free of congenital deformity and physical and psychological signs of disorder', but 'with the exception

74 See heredity form I-III in, e.g., JD, Cabinet-meeting document, 1917, 16 April, no. 38, Knut Törnquist, Maria Törnquist. Falling sickness is an older term for epilepsy.

75 JD, Cabinet-meeting document, 1915, 6 August, no. 29, Wilhelm Kaesen, Elisabeth Kaesen.

76 JD, Cabinet-meeting document,1916, 14 July, no. 30, Johan Westerberg, Anna Westerberg.

77 JD, Cabinet-meeting document,1916, 24 March, no. 43, Johan Hultkvist, Olga Hagström; JD, Cabinet-meeting document, 1916, 24 March, no. 41, Anders Bengtsson, Amanda Wretholm. 
of a mild case of varicose veins on both legs, a moderate case of flatfoot in both feet, and a visual acuity of 0.8 in the left eye'. ${ }^{78}$ One woman was said to be blind in one eye, and in another case it was noted that a man had reduced hearing. ${ }^{79}$

\section{The applicants' arguments}

The application documents were no longer dominated by people from the highest echelons of society. Indeed, the titles provided suggest that the majority of the applicants were from the working class. Only isolated cases concerned higher officials, such as engineers or managers. ${ }^{80}$

To all appearances, the applicants accepted the basic medical requirements. Men and women went to see a doctor and allowed themselves to be examined without objections, and childhood friends or acquaintances informed the authorities in detail about the family's general medical history. The medical circumstances were hence confirmed and reproduced as legitimate reasons for marriage impediments both from above and from below in society. Apart from this crucial factor, the lines of argument employed by applicants varied from being rational and matter of fact to emphasising personal emotions and expressing hopes for a happy marriage.

A hundred years earlier, at the turn of the century in 1800, applications for dispensation had been characterised by the applicants invoking practical as well as economic and emotional circumstances. Later in the nineteenth century, applications for dispensation increased in number, but the phrasing became more succinct and impersonal, and the emotional character was toned down. As the applications were very routinely processed by the middle of the nineteenth

78 JD, Cabinet-meeting document, 1916, 7 April, no. 37, Carl Carlsson, Emma Carlsson.

79 JD, Cabinet-meeting document, 1917, 2 February, no. 27, Fritiof Hjelm, Sofia Petersdotter; JD, Cabinet-meeting document, 1916, 29 September, no. 36, Hjalmar Andersson, Anna Linder.

80 The material contains sixty-four applications from fifty-three different couples. The men's professional titles included forty-three labourers, freeholders, or the equivalent (this includes, e.g., foundry workers or mill hands, farm and forest labourers, house owners, farm labourers paid in kind, seamen, linemen, station hands, painters, corporals, shopkeepers, smiths); six with middle positions (e.g., railway-line inspectors, master builders, packing-masters, supervisors, and engineers); one factory owner; and one manager. Two cases do not contain a title. 
century, there was no actual reason for arguing one's cause in great detail.

For the first time ever in Sweden, the amendment of the law in 1915 opened an opportunity for applying for dispensation in a new family category - diagonal consanguinity relationships (aunt, niece). But it was uncertain whether an application for such a marriage would be approved. This family relationship was perceived to be relatively close, and new medical arguments made the authorities disinclined to approve these marriages. Here, there was thus a new need for putting one's case in some detail. At the same time, the wording reveals an initial belief on the part of applicants that as long as the official requirements were fulfilled (health certificate, family-relationship certificate, and a testimonial from a clergyman), the application would be approved. Emanuel Carlsson wrote in his application that he and his niece had decided they wanted to marry. He invoked the new law, enclosing certificates on their state of health and their family relationships. ${ }^{81}$ When the application was rejected, the couple submitted a new application in which the tone was considerably meeker. Emanuel now asked 'most humbly' that the king 'by [his] grace' might approve their marriage. He claimed that it would be 'peculiarly hard' for them to separate, and that his future would in such a case be 'ruined' ${ }^{82}$ Knut Törnquist and his niece Maria Törnquist had a similar experience. Initially, they noted that they had 'taken a fancy' to each other, which is why they applied for formal permission to marry. ${ }^{83}$ When the application was rejected, they dispatched a new one containing a more detailed account of their 'mutual, heartfelt, and irresistible longing' to be married. They also wrote that a new rejection would cause them 'unsurmountable pain'. ${ }^{84}$ When this application was also rejected, they sent in a third request. Here they revealed that they already had a child together and enclosed a petition for clemency from Maria's parents, who made a 'heartfelt' and 'fervent' appeal for their daughter so that 'her grief would not send her to an untimely

81 JD, Cabinet-meeting document, 1916, 27 October, no. 33, Emanuel Carlsson, Anna Olsson.

82 JD, Cabinet-meeting document, 1916, 22 December, no. 32, Emanuel Carlsson, Anna Olsson.

83 JD, Cabinet-meeting document, 1917, 27 April, no. 38, Knut Törnquist, Maria Törnquist.

84 JD, Cabinet-meeting document, 1917, 14 June, no. 48, Knut Törnquist, Maria Törnquist. 
grave'. The parents claimed that there was no impediment to the marriage that was not outweighed by 'Christian love' and the need to support the small child. ${ }^{85}$ Although this application was rejected too, the couple did not give up. In a fourth and final application, they once more emphasised that they felt a 'deep and lasting' love for each other and invoked two new circumstances in their favour. Their persistence paid off, and in December 1918 they were finally given official permission to marry. ${ }^{86}$

As these cases show, a number of applications initially employed a rather businesslike tone of voice; but when the applicants were put under pressure, the tone became more personal and the argumentation more emotional. In various ways, the applicants emphasised that they loved each other and that their future happiness depended on their being allowed to marry. ${ }^{87}$

Even though several couples had 'lived in sin', their wish to legalise their relationship with a formal marriage appears to have been important to them. In their final application, Knut and Maria Törnquist pointed out that a marriage between them could not be considered 'offensive' by the public, whereas their relationship in its current form might well cause 'offence and aversion' ${ }^{88}$ In other words, it was more important for them to maintain and reproduce the marital norm than the incest prohibition. Knut Westin and his niece argued in a similar way in their second application for permission to marry. As they were already a couple and had children together, it should 'for civic reasons be of value that the [...] existing relationship was legalised' ${ }^{89}$

85 JD, Cabinet-meeting document, 1917, 14 December, no. 41, Knut Törnquist, Maria Törnquist.

86 JD, Cabinet-meeting document, 1918, 13 December, no. 108; JD K, 1918, 13 December, Knut Törnquist, Maria Törnquist. For more details regarding this case, see p. 249.

87 For additional examples where a couple's feelings for each other were emphasised as an argument for approval, see JD, Cabinet-meeting document, 1916, 12 May, no. 40, Anders Andersson, Augusta Gustavsson; JD, Cabinet-meeting document, 1917, 13 August, no. 28, Hjalmar Andersson, Anna Linder; JD, Cabinet-meeting document, 1917, 2 February, no. 27, Fritiof Hjelm, Blända Petersdotter; JD, Cabinet-meeting document, 1916, 24 March, no. 42, Martin Viberg, Hanna Blomberg.

88 JD, Cabinet-meeting document, 1918, 13 December, no. 108, Knut Törnquist, Maria Törnquist.

89 JD, Cabinet-meeting document, 1917, 18 January, no. 62, Knut Westin, Gerda Lundgren. 
Similar values occur in the testimonials submitted by clergymen. In the testimonials from the middle of the nineteenth century, the clergy often provided neutral information about the repute and scriptural knowledge of the applicants. To be sure, one might say that the clergymen in question supported the applicants' desire to marry by writing testimonials in the first place; but this stance was not actively articulated. ${ }^{90}$ In the applications from the 1910 s, by contrast, a vicar often supported the cause of the applicants by conveying personal views and recommendations. One perpetual curate wished 'most heartily' to recommend a marriage between two applicants. ${ }^{91}$ One vicar felt that a marriage would be 'desirable' for several reasons. ${ }^{92}$ Another vicar felt that it would be better 'from the societal point of view' if a couple were allowed to marry, because they already lived together and because it was likely they would continue to do so even if the application was rejected. ${ }^{93}$ In one application for dispensation, a vicar recommended that the desired marriage should be approved because the woman in question and her extramarital children would thereby be supported and 'not have to be a burden on the poor relief'. ${ }^{94}$ In another case, a lawyer supported a couple who also applied for permission to marry. ${ }^{95}$

90 For instance, in material from 1850 the clergyman in question testified to conduct, repute, and scriptural knowledge in an impersonal way in twentynine out of thirty-five applications. In a mere two cases were statements made that may, with some generosity, be thought to amount to an active adoption of a position, i.e., JR, BoA 1850, 17 April, Lars Rasmusson, Kierstin Pehrsdotter; JR, BoA 1850, 9 July, Jan Jansson, Anna Andersdotter.

91 JD, Cabinet-meeting document, 1917, 2 February, no. 27, Fritjof Hjelm, Blända Petersdotter.

92 JD, Cabinet-meeting document, 1917, 23 March, no. 32, Valfrid Andreasson, Ellen Karlsson. The reasons stated were that the man was quite poor and had a wooden leg, which made it improbable that anybody else would want to marry him; that the man lived with his mother who was old and for this reason incapable of keeping house; and that the couple already lived together and were expecting an addition to the family.

93 JD, Cabinet-meeting document, 1917, 6 July, no. 34, Oskar Carlström, Helga Carlström.

94 JD, Cabinet-meeting document, 1919, 13 January, no. 38, Olof Dalberg, Sigrid Dalberg. For additional statements, see, e.g., JD, Cabinet-meeting document, 1916, 12 May, no. 40, Anders Andersson, Augusta Gustavsson; JD, Cabinet-meeting document, 1919, 18 January, no. 67, August Lundskog, Kristina Lundskog; JD, Cabinet-meeting document, 1919, 28 May, no. 41, Salomon Karlsson, Olivia Mårtensdotter; JD, Cabinet-meeting document, 1916, 14 July, no. 30, Johan Westerberg, Anna Westerberg.

95 JD, Cabinet-meeting document, 1916, 17 November, no. 32, Anders Lindh, Anna Svensson. 
It is true that there was not a high incidence of applications for marriages between people who were related in the diagonal consanguinity degree, but nor does there seem to have been a principled aversion to such relationships. Relationships where it was made clear that the applicants had warm feelings for each other were supported by the community. In these cases, practical and economic circumstances as well as emotional attachments were perceived to be more important circumstances than the family relationship. In other words, couples, like the people who took up an active position in the case by submitting various certificates, felt that it was more important to defend the marital norm than to respect the formal incest prohibition. Marriage was described as the best solution for the individuals in question and for society at large. As in earlier periods, this marital norm was defended in principle by the authorities as well. The Act of 1915 established that from a societal perspective, marriage was 'the only desirable form of sexual relationship'. At the same time, it was noted that marriage also constituted an important prerequisite for 'the happiness and personal development of the individual'. ${ }^{96}$

In addition, it is clear that the right of an individual to personal happiness was a stronger argument than ever before. Apart from couples themselves emphasising their emotions, clergymen referred to the applicants' personal desires as legitimate reasons for their being allowed to marry. In a testimonial, vicar Vilhelm Larsson said that he had visited the couple in question and made sure that their desire for marriage was sincere. They were, according to his assessment, sincerely 'attached to each other' and had a 'heartfelt desire' to marry. ${ }^{97}$ Another man and woman had taken a fancy to each other when in service at the same place. The perpetual curate commented that the couple should be allowed to marry for their 'own good'. ${ }^{98}$ In what appears to be farm labourer Bror Johansson's personally formulated application, the same priorities were expressed with particular clarity:

To His Royal Majesty! I wonder if Your Majesty would allow me to marry my father's half-sister we have fallen in love so we cannot

96 Lag om äktenskapets ingående och upplösning, p. 31.

97 JD, Cabinet-meeting document, 1917, 6 July, no. 34, Oskar Carlström, Helga Carlström.

98 JD, Cabinet-meeting document, 1916, 12 May, no. 40, Anders Andersson, Augusta Gustavsson. 
be parted other than through death so I thought I would ask Your Majesty if it is a hindrance that we are a little bit related I don't think it should make any difference if Your Majesty would be so kind as to let me know as soon as Your Majesty receives this letter I would be profoundly grateful. Yours faithfully B. G. Johansson ${ }^{99}$

Here both the handwriting and the wording indicate a limited education, but Bror's opinions cannot be doubted. His and his fiancée's feelings were too strong to be ignored. They loved each other and could not be separated other than by death, whereas the impediment to a legalisation of their relationship through marriage merely consisted of their being 'a little bit related'. This example, like previous ones, implies that it was far more important to defend an opportunity for personal happiness by forming a loving marriage than to respect the prohibition against marriage in the diagonal consanguinity degree.

In summary, it may be noted that although applications frequently began with an impersonal tone, love and future happiness were used as leverage when the applicants attempted to increase their chances of having their application for permission to marry approved. Several relationships had been going on for some time, which meant that two prohibitions were challenged simultaneously: the prohibition against sexual relations between unmarried people, and the prohibition against sexual relationships between relatives (aunt, niece). Here the marital norm was prioritised in favour of the incest prohibition not only by the applicants themselves but also by people around them. No one protested against medical arguments as potential impediments to marriage. While several couples had begun their sexual relationship long before they applied for permission to marry, all couples submitted to a personal medical examination without apparent protest and described their own and their respective families' medical history in detail. In other words, ideas on medical circumstances being legitimate impediments to marriage were reproduced by the decision-making authorities as well as by the general public. For this reason, it would be easy to assume that the applications that were rejected were commonly denied on medical grounds. When examining the outcome of the applications, however, this turns out not to be the case.

99 JD, Cabinet-meeting document, 1920, 26 November, no. 73, Bror Johansson, Ida Svensson. My italics. 


\section{Medical and social circumstances and age difference}

The analysis of the applications for dispensation from the 1910s is made easier by the fact that the reasons that the authorities found decisive were often marked by underlinings in pencil or by a summarising note in the application itself. ${ }^{100}$ These informal markings can be checked against the arguments that were presented in the official reports of the National Swedish Board of Health. The opinions of the National Swedish Board of Health were usually presented in two parts: a fairly long, detailed report (memo) and a very brief summary of the case along with the decision of the Board.

Both the Civil Code of 1734 and the Act of 1864 expressly stated that full and half relatives should be considered legally equivalent. In the marriage act of 1915 , this formulation was removed; but the explanatory statements emphasised that full and half relatives should nevertheless be treated equally in future as well. ${ }^{101}$ In spite of this, all the material shows that the authorities took account of whether a relationship was full or half, both in criminal and in dispensational cases, in the early twentieth century. Time and time again, decisions in the dispensational material were justified by using the family relationship as an argument. Rejections were considered justified 'in particular because the applicants are full relatives', while decisions on approvals were reinforced by the relevant case 'being only a matter of half-relatives'. ${ }^{102}$ Around a third of the sixty-four applications came from people who were half-relatives. ${ }^{103}$ All of them were approved.

The other assessments emphasised three factors: medical impediments, social circumstances, and the age difference between the

100 See, e.g., JD, Cabinet-meeting document, 1916, 28 April, no. 48, Johan Johansson, Elsa Olsson; JD, Cabinet-meeting document, 1916, 12 May, no. 36, Carl Johansson, Ester Johansson; JD, Cabinet-meeting document, 1916, 29 September, no. 36, Hjalmar Andersson, Anna Linder; JD, Cabinet-meeting document, 1916, 23 March, no. 32, Valfrid Andreasson, Ellen Karlsson; JD, Cabinet-meeting document, 1919, 28 May, no. 41, Salomon Karlsson, Olivia Mårtensson.

101 Lag om äktenskapets ingående och upplösning, p. 45.

102 See, e.g., JD, Cabinet-meeting document, 1916, 24 March, no. 41, Erik Ljungdahl, Astrid Johansson. A similar wording can be found in more or less all of the applications regarding half-relatives. For examples of full relatives, see JD, Cabinet-meeting document, 1917, 16 February, no. 39, Wilhelm Kaesen, Maria Kaesen.

103 Or, to be more precise, twenty-one out of sixty-four applications. 
applicants. Surprisingly enough, it was most often the last-mentioned factor - the age difference - that was decisive for the outcome.

When an application was to be assessed, the medical circumstances were checked first and foremost. In order to gain knowledge of the appropriateness of the applicants getting married and potentially having children, the state required, via a medical examination and certificate, a confirmation of the applicants' being in full health and not at risk of passing on bad genes to the next generation. Any liabilities could lead to a swift rejection. Olof Tjärnlund and his niece Maria Johansson were, for instance, denied permission to marry because there was a brother and two cousins in their extended family who had been admitted to an asylum and two sisters who suffered from epilepsy. ${ }^{104}$ But in spite of the sharp focus placed on a family's medical history, it was possible for people with known disorders in the family to be given permission to marry. In the application from Karl Muhr and Anna Sandelius, it was stated that Karl's father had become mentally ill in his old age and had died in an asylum. Even so, the couple were given permission to marry. ${ }^{105}$ Oskar Nordström and his half-niece Johanna Blomkvist were also allowed to marry, although there were relatives on Oskar's side who showed signs of mental disorder and epilepsy. The National Swedish Board of Health said that because the disorder only existed on Oskar's side of the family, there were no medical impediments to the marriage. The Crown followed the recommendations of the National Swedish Board of Health and approved the couple's application. ${ }^{106}$ Another man had a sister who was 'mentally deficient' while his fiancée and niece had a 'feeble-minded' aunt. The disorder of both the sister and the aunt was, however, said to have appeared after a childhood disease, and the couple were given permission to marry. ${ }^{107} \mathrm{~A}$ mental disorder in the family hence did not automatically result in the rejection of a couple's application, if the risk of the disorder being passed on to the next generation was considered to be slight. Surprisingly enough, the proportion of applicants who

104 JD, Cabinet-meeting document, 1920, 26 March, no. 43; JD, R, 1920, 26 March, no. 42, Olof Tjärnlund, Maria Johansson.

105 JD, Cabinet-meeting document, 1916, 22 July, no. 31; JD, K, 1916, 22 July, no. 93, Karl Muhr, Anna Sandelius.

106 JD, Cabinet-meeting document, 1916, 22 December, no. 31; JD, R, K, 1916, 22 December, Oskar Nordström, Johanna Blomkvist.

107 JD, Cabinet-meeting document, 1916, 23 March, no. 32, Valfrid Andreasson, Ellen Karlsson. 
were rejected because of their own disorders, or disorders in their families, was very small. Out of sixty-four applications, twenty-three were rejected. In only one case was the rejection based solely on medical grounds, namely the above-mentioned case of Olof Tjärnlund and Maria Johansson. In other cases, it was usually the age difference that put an end to the applicants' wedding plans. ${ }^{108}$

Age difference was the single most common justification for rejection, and its importance for the assessment of the applications for dispensation becomes apparent in several ways. The age of the applicants was mandatory information that had to be stated before the application was processed. The information should preferably be verified by way of a certificate from a clergyman who knew the family personally; alternatively, written information from the parish registers could be certified by the clergyman on duty. The ages of the applicants were very often underlined in pencil in the application documents, regardless of whether the application was rejected or approved. In addition, there were cases where the exact ages of - or the age difference between - the applicants were stated in the precise terms of years, months, and days. ${ }^{109}$

In their assessments, the National Swedish Board of Health thus always took the ages of the applicants into consideration. Indeed, information about ages seems to have overshadowed the medical circumstances in some cases. Karl Pettersson was sixty-eight years old and his niece Hilma Andersson was thirty-seven. Consequently, there were a little over thirty years between Karl and Hilma. Via medical certificates and testimonials about their families from acquaintances, it was noted that there were mental disorders in both Karl's and Hilma's families. They had three common relatives who either suffered from epilepsy or had been diagnosed as mentally ill. The medical liabilities were carefully stated in the report of the National Swedish Board of Health, but in the summary of the case these disorders were not mentioned at all. Conversely, the summary

108 Fifteen rejections were justified solely on the basis of a great age difference; two rejections were justified on the basis of a great age difference in combination with another impediment. One case was rejected because factual information was missing, and in some cases the reasons for rejection were not stated in detail but can be assumed to have had to do with the applicants' family positions relative to each other. See further discussion on pp. 251-3.

109 See, e.g., JD, Cabinet-meeting document, 1917, 9 November, no. 66, Frans Svenningsson, Ellen Svenningsson. 
announced that the National Swedish Board of Health 'owing to the significant age difference between the applicants, cannot approve the submitted application'. ${ }^{110}$ Karl and Hilma's application would probably have been rejected even if they had been closer in age; but it is very interesting that the National Swedish Board of Health chose to foreground age as being decisive for the outcome, and that the large age difference led to a rejection 'from a medical point of view'. Similar words were employed in a different case where there were no liabilities in the form of disorders in the applicants' family history. There was an age difference of thirty-five years between Johan Skog (sixty-one) and his niece Emilia Skog (twenty-six). Both Emilia and her father confirmed in separate certificates that they consented to the planned marriage and that there were no signs of disorders in the family. The application was rejected with the following wording: 'In view of the significant age difference, around thirty-five years, that exists between the applicants, the National Swedish Board of Health finds itself unable to recommend approval for the submitted application for medical reasons. ${ }^{111}$

The National Swedish Board of Health thus described a significant age difference as a medical impediment. Professor Frej Svensson, who was chairman of the National Swedish Board of Health scientific council, presented his view of the matter in a written opinion dated 31 March 1917. He declared that the age difference between two spouses was of importance for the offspring from a hereditary perspective, because the gametes came from individuals at 'different stages of development'. This was, he argued, of particular significance when either of the individuals was outside his or her 'most potent age of procreation', that is to say, was not at the optimal age for producing children. If the man was under twenty-five years old or over fifty, or if the woman was under twenty or over forty, marriages should not be allowed between couples where the age difference was greater than twenty years. However, it was not made clear in concrete terms how this age difference might affect a child. Furthermore, Svensson stated that marriages between men and women with a greater age difference than twenty years were inappropriate from a social perspective as well. The man's age was

110 JD, Cabinet-meeting document, 1920, 16 January, no. 77, Karl Pettersson, Hilma Andersson.

111 JD, Cabinet-meeting document, 1919, 31 July, no. 46, Johan Skog, Emilia Skog. 
especially important in this context, as the social reasons were connected to the man's ability to support and raise a child. A child was assumed to require support from its parents up until the age of fifteen. The recommended age limit for a man's parenthood was therefore set at the age of fifty-two, when he had fifteen years left to retirement. ${ }^{112}$

The legislation did not lay down any limitations for marriages on the basis of age difference between the man and the woman. ${ }^{113}$ Neither was age difference, judging from the printed protocols from the joint preparatory legislative work, debated as a circumstance that impeded marriages in this arena. ${ }^{114}$ Nor were there limitations preventing unrelated couples from marrying if there was a great age difference between the prospective spouses.

That spouses should preferably be fairly close to each other in age must instead be seen as an informal norm in society. There are early examples of a great age difference between a husband and wife being perceived as an unfavourable circumstance which should be avoided in order to increase the likelihood of a happy marriage. ${ }^{115}$

112 JD, Cabinet-meeting document, 1917, 27 April, no. 38, Knut Törnquist, Maria Törnquist.

113 Nya äktenskapslagen med förklaringar; Lag om äktenskapets ingående och upplösning.

114 In a little over one hundred typewritten pages, the legislators' motives for legitimising the marriage impediments are described. On one single occasion, it is noted in a subclause that diagonal consanguinity relationships were inappropriate 'especially because there is often a great age difference between the contracting parties'. Lagberedningens förslag till revision av giftermålsbalken...I, pp. 129-239, quotation on p. 199.

115 In 1711, a couple were advised against marrying because of an age difference of about forty years; but because both parties consented to the marriage, their wish was eventually granted by the Cathedral Chapter in Skara. SD, A1:30, 1711, 27 September, no. 17; SD, AI:30, 1711, 11 October, no. 175. In one case from the Strängnäs Cathedral Chapter, 'an old man of about a hundred years' wanted to marry a thirty-year-old maidservant. She was in service with him, and both his and her relatives consented to the marriage. The Cathedral Chapter approved their application in October 1676. StD, AI:II, 1686, 30 September, no. 3, p. 128; StD, AI:11, 1686, 6 October, no. 5, pp. 129f. Marklund refers to another case where the woman was almost forty years older than the man. After valiant attempts to prevent the union, the vicar married them. Marklund 2004, pp. 175, 192-94. Sandén also describes cases where odd couples have initially been dissuaded from getting married but eventually had their way. Sandén 2005, pp. 178f. See also Liliequist 2007, p. 180. 
This norm is also indirectly expressed in dispensational cases where couples stated that they were close to each other in age as an argument for having their applications approved. ${ }^{116}$ Although these are isolated cases, it is possible to conclude that certain ideals surrounding marital unions existed in which a great age difference between the spouses was seen as potentially detrimental. It is, however, uncertain how widespread or influential these notions were during earlier periods.

The pattern of marriages in Sweden corresponded to what has been called the Western European marriage pattern. This meant that men and women, unlike the situation in Eastern Europe, only married when they were able to form a household and support themselves. In the old agrarian society, that stage was often attained around the age of twenty-five. Among peasants, the age difference between husband and wife was relatively small at the time of the first marriage, whereas around ten years' difference between a man and his younger wife was more common in the higher estates. ${ }^{117}$ Nevertheless, some studies indicate that the aversion to too great an age difference between spouses was more pronounced in the higher ranks than among the peasantry. ${ }^{118}$ In a second and third marriage, the age difference between the spouses frequently widened with respect to the peasantry, too, because a widow or widower commonly remarried a previously unmarried younger person, rather than merging two established households. In cases where a widow remarried, it was thus not uncommon for the woman to be older than the man. ${ }^{119}$ Besides, up until the second half of the eighteenth century, the custom of widow conservation was well established within both the clerical estate and the artisanal groups. ${ }^{120}$

Even though there have been certain norms regarding the ages of spouses during earlier periods, one can thus draw the conclusion

116 JR, BoA 1780, 25 February, Magnus Norling, Catharina Söderström; JR, BoA 1801, 28 October, Joseph Rautiain, Ulrika (cousin); JD, Cabinet-meeting document, 1920, 3 December, no. 56, Lars Wiberg, Herta Liljeroth.

117 On the Western European marriage pattern, see Coontz 2005, pp. 124-31; Gaunt 1996, pp. 14-19. On the age difference between spouses in the higher estates, see Davidoff, Doolittle, Fink, and Holden 1999, p. 126; Carlsson 1977, p. 109; Stadin 2004, p. 178.

118 Lennartsson 2012, pp. 105, 107f, 112; Sandén 2005, pp. 178, 180.

119 Gaunt 1996, pp. 178-80; Matović 1984, pp. 121, 130, 176; Göransson 1992, p. 119; Taussi Sjöberg 1988, pp. 72-4.

120 Widén 1988; Vainio-Korhonen 1997; Edgren 1983. 
that these norms were not decisive for people's actions. If a marriage was considered advantageous for other reasons, the parties' ages relative to each other did not constitute an impediment to the alliance, neither among the peasants nor among the higher orders. The fact that information about a couple's respective ages was rarely recorded in connection with criminal trials and dispensational cases before the turn of the century in 1800 must also be taken to indicate that age was not regarded as relevant to the decisions. Over time, however, a change appears to have taken place.

Although the custom of widow conservation dwindled during the nineteenth century, historian Ulla Rosén, in a study on care of the elderly in the Swedish agrarian society, has shown that remarriage was used as a strategy for elderly care throughout the 1800 s. Conversely, the number of marriages where there was a great age difference between the spouses declined at the beginning of the twentieth century, after various societal resources geared to supporting the elderly had been introduced. ${ }^{121}$ According to the research of historian Margareta Matović, the general marriage pattern in Stockholm also changed during this time. In the 1860s and 1870s, it was relatively common for a woman to be older than a man in the lower social orders, even with respect to first marriages; but towards the end of the century, such alliances became increasingly rare. ${ }^{122}$ Marja Taussi Sjöberg showed that there was a similar declining trend for older wives with younger husbands in northern Sweden during the same period. ${ }^{123}$ Even though the proportion of older women did not decrease in the same way when it came to remarriages, the statistics can be interpreted as meaning that Sweden saw a cultural shift with regard to age differences between spouses during the second half of the nineteenth century. As a consequence of that shift, people in general were less prepared to accept great deviations in age, and nor would they approve of older wives and younger husbands. When the ages of couples applying for dispensation became decisive for the outcomes of cases at the beginning of the twentieth century, it may have been connected to this cultural shift.

Regardless of the general attitude to the ages of husbands and wives in earlier periods, ideas about the ages of spouses thus acquired a decisive importance in the assessment of applications for dispensation during the 1910s. All couples where the age difference was

121 Rosén 2004, pp. 145 f.

122 Matović 1984, p. 184.

123 Taussi Sjöberg 1988, pp. 72-4. 
greater than twenty years were initially denied permission to marry, and some couples were rejected even when the difference was just below twenty years. ${ }^{124}$ Here, then, the National Swedish Board of Health seems to have been influenced by informal ideas about how an optimal marriage should be configured. The decisions, and the informal ideas on which those decisions were based, were justified internally by means of 'scientific' opinions submitted by experts, but those opinions did not present any support for the scientific arguments.

The fact that an application for marriage could be rejected because of a significant age difference appears to have come as a surprise to the applicants. In their first application from 1916, Hjalmar Andersson (fifty-three years old) and his niece Anna Linder (twenty-nine years old) stated that they, like all their relatives, were completely healthy, whereupon they invoked the new law and asked for permission to marry. All the submitted information was supported by enclosed certificates, and at the end of their formal letter the couple noted that they could not imagine that there could be any 'objections' to their marriage for 'medical reasons'. ${ }^{125}$ There were twenty-four years between Hjalmar and Anna, and their application was rejected. ${ }^{126}$ One year later they made a new attempt. From their second application, it transpires that Hjalmar and Anna had been encouraged in their desire to marry by doctors and lawyers, who had assumed that their application would be approved. Encouraged by this unofficial support, they had 'become formally engaged and exchanged rings' and planned to live together. The rejection had 'hit them hard', and they questioned the twenty-year limit, which was 'completely arbitrary'. In addition, they felt that they only exceeded the limit 'in an insignificant way'. What was more

124 JD, Cabinet-meeting document, 1917, 16 February, no. 39; JD, K, 1917, 16 February, Wilhelm Kaesen, Elisabeth Kaesen; JD, Cabinet-meeting document, 1919, 31 July, no. 46; JD, K, 1919, 31 July, Johan Skog, Emilia Skog; JD, Cabinet-meeting document, 1916, 29 September, no. 36; JD, K, 1916, 29 September, no. 245, Hjalmar Andersson, Anna Linder; JD, Cabinet-meeting document, 1917, 27 April, no. 38; JD, K, 27 April, no. 199, Knut Törnquist, Maria Törnquist; JD, Cabinet-meeting document, 1916, 12 May, no. 41; JD, K, 1916, 12 May, Erik Ljungdahl, Astrid Johansson; JD, Cabinet-meeting document, 1916, 12 May, no. 40; JD, K, 1916, 12 May, no. 86, Anders Andersson, Augusta Gustavsson.

125 JD, Cabinet-meeting document, 1916, 29 September, no. 36, Hjalmar Andersson, Anna Linder.

126 JD, K, 1916, 29 September, no. 245, Hjalmar Andersson, Anna Linder. 
important was that they themselves and all their relatives were 'in the best of health'. They found it to be 'distressing' if their union and 'future happiness' were to be thwarted by medical objections. ${ }^{127}$ By choosing the expressions they used, both Hjalmar and Anna recognised that the health issue was important and relevant in the context, but they did not accept that the age difference should be relevant to the decision. However, the couple did not succeed in convincing the authorities, and their second application was turned down as well. ${ }^{128}$ A number of couples repeated their applications in a similar way after a rejection when age difference was stated as a reason. ${ }^{129}$ I interpret this as a direct protest against the state's right to decide on these matters. In other words, a great difference in age was not accepted by the applicants as a legitimate impediment to marriage.

Although Hjalmar and Anna were unsuccessful, some couples managed to get decisions amended and their applications approved after repeated applications, in spite of there being a great age difference between them. ${ }^{130}$ In these cases, it was social circumstances that caused the authorities to change their minds. In one application, a vicar entreated that the marriage between Oskar Carlström (fortythree years old) and his niece Helga Carlström (twenty-one years old) should be allowed to take place. The vicar did not understand why this marriage could not be approved now that the amended law had eliminated the 'fundamental' objections one might have had against such unions in the past. He did not mention the age difference between Oskar and Helga. Instead he emphasised that the applicants were well-behaved and hard-working. Though Helga and Oskar were already living together, their intimate relationship

127 JD, Cabinet-meeting document, 1917, 13 August, no. 28, Hjalmar Andersson, Anna Linder.

128 JD, K, 1917, 13 August, no. 89, Hjalmar Andersson, Anna Linder.

129 Examples of renewed applications where the rejection had been linked to the age difference: JD, Cabinet-meeting document, 1917, 16 February, no. 39, Wilhelm Kaesen, Elisabeth Kaesen; JD, Cabinet-meeting document, 1919, 31 July, no. 46, Johan Skog, Emilia Skog; JD, Cabinet-meeting document, 1916, 22 December, no. 32, Emanuel Carlsson, Anna Olsson; JD, Cabinet-meeting document, 1917, 23 June, no. 34, Oskar Carlström, Helga Carlström.

130 The applications of fourteen couples in total were rejected, of which half appealed against the decision at least once. Out of these, only four couples managed to have the decisions changed. Two of these four applied three and four times, respectively, before the decisions were amended. 
had developed without their having endeavoured to make it happen. The couple had had one child together who had died, and the vicar felt that it would help them in their grief if they were allowed to marry. In conclusion, he noted that the couple were so devoted that it would be very difficult for them to be separated. Again, personal desires, practical circumstances, and economic relationships were foregrounded as arguments for approving a marriage. The National Swedish Board of Health allowed itself to be persuaded, their summary of the case stating that there were no reasons for rejection 'from a medical perspective', whereupon the Crown approved the application even though there were twenty-two years between Oskar and Helga. ${ }^{131}$ Similarly, another couple had their application for permission to marry approved in spite of an age difference of a little over twenty years. In this case, the woman was said to have lived with and kept house for her intended husband for five years. ${ }^{132}$

After four applications, the previously mentioned couple Knut Törnquist (forty years old) and his niece Maria Törnquist (seventeen years old) also managed to be given permission to marry despite there being an age difference of more than twenty years between them. In the first opinion of the National Swedish Board of Health, a disorder in the family (one sister was said to be mentally ill after a childhood disease), Maria's youth, and the great age difference (twenty-two years) were stated as impeding circumstances. The second and third applications repeated the same arguments. References to Professor Svensson's opinions on the age difference between spouses were also made several times. When the three initial applications were submitted Maria was only seventeen years old, which was below the legal age for marriage, and she was said to be a full relative of Knut's. When the fourth and final application was submitted Maria had turned eighteen, and besides the couple claimed that they were only half-relatives. In line with this new information, Maria was thus only Knut's half-niece. The final opinion of the National Swedish Board of Health confirmed that this new information was decisive, and that in view of it, the Board no longer 'had any objections to make against an approval'. The fact that the age

131 JD, Cabinet-meeting document, 1917, 23 June, no. 34; JD, K, 1917, 6 July, no. 40, Oskar Carlström, Helga Carlström.

132 JD, Cabinet-meeting document, 1919, undated decision, received 18 January, no. 67, August Lundskog, Kristina Lindskog. 
difference between Knut and Maria was over twenty years was not commented on in the final opinion. ${ }^{133}$

Initially, then, couples where the age difference was close to or exceeded twenty years had their applications rejected; but if a couple repeated their application and there were no other obstacles, the National Swedish Board of Health might reconsider their assessment. Often it was social or economic circumstances that decided these cases. Couples who lived and had children together stood a greater chance of having their applications approved than couples who had not yet initiated a sexual relationship. One application specifically mentioned that it would be desirable, especially for the woman and her children, if the relationship could be legalised, so that their 'mutual home [...] could continue'. The Crown subsequently approved the couple's application, though there was an age difference of nineteen years and seven months. ${ }^{134}$ In one application, the Board summarised previous decisions. Without exception, the justification for all decisions had to do with social circumstances or the ages of the parties. ${ }^{135}$

Unlike the state of things in previous periods, when known immorality lessened the chances that a couple applying for dispensation would secure a favourable decision, information about living together and having mutual children could increase the chances of approval in the 1910s. Consequently, the absence of these factors could be a cause of rejection. On the front page of a rejected application, it is written in pencil: 'as far as is known no child and have not lived together'. ${ }^{136}$

The authorities hence took the social circumstances of the couple into consideration. There was reluctance to break up established relationships, especially if children were involved. The very circumstances which had previously been perceived as aggravating and

133 JD, Cabinet-meeting document, 1918, 13 December, no. 108; JD K, 1918, 13 December, Knut Törnquist, Maria Törnquist.

134 JD, Cabinet-meeting document, 1916, 14 July, no. 30; JD, K, 1916, 14 July, no. 56, Johan Westerberg, Anna Westerberg.

135 JD, Cabinet-meeting document, 1917, 9 November, no. 66, Frans Svenningsson, Ellen Svenningsson.

136 JD, Cabinet-meeting document, 1916, 12 May, no. 41, Erik Ljungdahl, Astrid Johansson. See also a case where the application was rejected because it could not be proved that the man was the child's father. JD, Cabinet-meeting document, 1917, 16 February, no. 39; JD R, K, 1917, 16 February, Wilhelm Kaesen, Elisabeth Kaesen. 
which many applicants had attempted to keep secret from the state - that they were a loving couple, that they lived together, that they had children - were reasons promoting a favourable assessment. For some couples, this lack of knowledge may have led to their giving up their plans to marry after an initial rejection. Fredrik Engström (thirty-six years old) and his aunt Anna Holmgren (thirtyeight years old) barely managed to avoid such an outcome. The first two applications of this couple were, like those of many others, brief and to the point without revealing any detailed information about their personal lives. When these applications were rejected, two more years elapsed before a third application was drawn up. A personal letter from Anna, where she described her life and where she admitted to already having a relationship with Fredrik, was enclosed with the final application. She described how she, 'young and inexperienced', had come to Stockholm to live with her elder sister. Her sister's family was described as poor and socially dysfunctional. Anna was exploited as an unpaid household help and as a babysitter, and at the same time she found it difficult to protect herself from her brother-in-law's unwelcome advances. Regarding her sister's eldest child Fredrik, who was the same age as Anna, she wrote:

The eldest boy saved me from his father many times. He was quiet and sad and different in character from both his father and his mother. For this reason he was never accepted in the home. The consequence was that he turned to me. I respected him and felt sorry for him. It continued in this way until I realised I loved him. ${ }^{137}$

A few years later, Anna and Fredrik moved to a home of their own and assumed responsibility for raising a girl who had been badly treated in her own home. In her letter, Anna emphasised that it would be considerably better for this child if Anna and Fredrik were allowed to marry, so that the girl would not be teased by her friends. These circumstances had not been mentioned in the previous applications, she admitted, because the couple had, in their 'great foolishness', believed 'that it would be better that way'. Anna's candid letter met with approval, and the couple were given permission to marry in September 1918.

It may be noted that Anna was Fredrik's aunt, which is likely to have been the reason why their previous applications had been

137 JD, Cabinet-meeting document, 1918, 18 September, no. 50, Fredrik Engström, Anna Holmgren. 
rejected (there was only an age difference of two years between them, and there were no known disorders in the family). The National Swedish Board of Health did not find any medical impediments to their marriage in the first application rounds, but the Crown nevertheless chose to reject their application without any particular justification. ${ }^{138}$ The material contains twenty-nine relationships between a man and his niece, but only two relationships between a man and his aunt. ${ }^{139}$ There were thus only a few couples who applied for permission to marry when the woman's family position was in the generation above the man's. The numbers indicate that there were still ideas rife in society regarding the importance of the family position for romantic relationships. The acceptance of a relationship between a man and his niece had been greater than the acceptance of a relationship between a man and his aunt for a long time, and these notions were a probable reason for the rejections of Fredrik and Anna's previous applications.

The importance of family position in this context is also illustrated by the only application for marriage where the applicants were related in an affinity degree. The case involved a man and his stepdaughter. Lars Wiberg (thirty-five years old) wrote to the king during the autumn of 1920 , asking for permission to marry his stepdaughter, Herta Liljeroth (twenty-eight years old). When Lars had married Herta's mother a few years earlier, Herta was already an adult and had moved away from home. In addition, she had been married herself and had three children of her own. After Lars's wife and Herta's husband had died, they now wanted to marry. Lars justified his application in the following way:

Because no blood relationship thus exists between us, because furthermore Herta Liljeroth has never resided in my home, or in any other way perceived herself to be in the relationship of a child to me, the less so as we are approximately of the same age, and, in conclusion, because we have now grown extremely fond of each other ... ${ }^{140}$

138 The first application was rejected because of incomplete information, the second without any particular justification. JD, Cabinet-meeting document, 1916, 8 September, no. 49; JD, Cabinet-meeting document, 1916, 8 September, no. 34; JD, K, 1916, 8 September, no. 77, Fredrik Engström, Anna Holmgren.

139 Including half-nieces and half-aunts, the figures total forty-five and seven relationships, respectively.

140 JD, Cabinet-meeting document, 1920, 3 December, no. 56, Lars Wiberg, Herta Liljeroth. 
The application was rejected with the brief justification that it was in opposition to existing law. Consequently, there was no scope for exceptions in this case. Lars's application stressed several circumstances which he felt distinguished their relationship from the relationship that the legislation had in view: that there was no biological kinship between them; that they had never lived together in the same household; that they had never been in a parent-child relationship with each other; that they were almost same age; and that they had 'taken a fancy' to each other. All these circumstances were ignored by the authorities. As in earlier periods, there were thus strong ethical objections in society against sexual relationships between family members in lineal kinship degrees. In this case, the objections were based entirely on the family positions of the applicants relative to each other. The fact that no other applications for marriage were submitted for similar relationship categories increases the likelihood that these ideas were also shared by the public.

\section{Criminal cases}

Although incest has always been a relatively uncommon crime, it became even rarer in Swedish courts around the turn of the century in 1900. In the 1910s, only about ten people per year were prosecuted for and convicted of incest in Sweden. The figures rose somewhat during the subsequent decades (approximately twenty to thirty) only to drop again after 1930. It is likely that the temporary increase may be ascribed to newly introduced laws on child welfare, which resulted in more crimes being discovered and reported. ${ }^{141}$

In the 1930s, two scientific studies were conducted concerning the prevalence of the crime of incest in the country. Torsten Sondén, a reader in psychiatry, investigated court material for incest crimes between 1913 and 1933, involving just over 150 convicts. His preliminary conclusions were presented in 1935, in connection with an official government inquiry about the ranges of punishment for particular crimes in Sweden. ${ }^{142}$ Another contemporaneous study used material from one hundred Swedish incest cases between 1929

141 The number of prosecuted families is said to have been around ten per year in 1913-18, twenty per year in 1919-27, thirty per year in 1928-30, and twenty per year in 1931-3. SOU 1935:68, p. 47. Similar figures are given for the number of persons convicted during the same time. Kinberg, Inghe, and Riemer 1943, p. 45.

142 SOU 1935:68. 


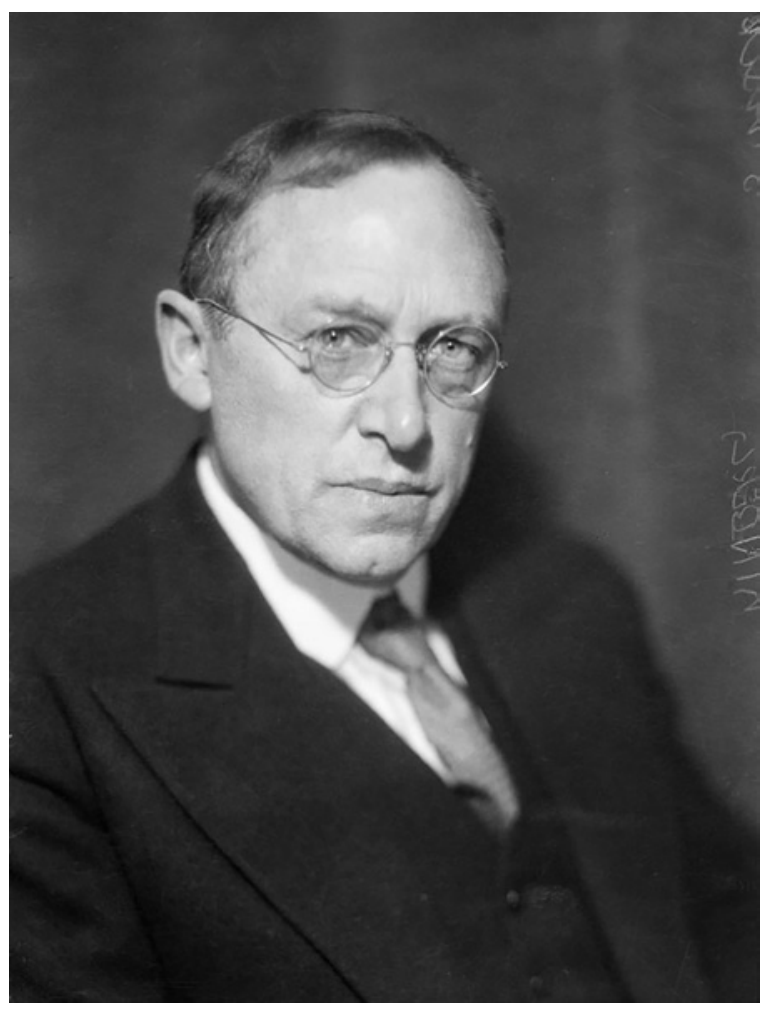

18 Olof Kinberg (1873-1960), physician, psychiatrist, and co-author of Incestproblemet $i$ Sverige ('The incest problem in Sweden'), which was published in 1943.

and 1937. The authors of this study were Olof Kinberg, at that time a teacher of forensic psychiatry and psychiatrist at the central prison of Långholmen; Gunnar Inghe, active within social medicine and the editor of Populär tidskrift för sexuell upplysning ('Popular periodical for sexual information'); and Svend Riemer, a German academic and later a professor of sociology in the United States. ${ }^{143}$

In connection with these investigations, the phenomenon of incest was analysed from a number of perspectives. Quantitative studies were made concerning the prevalence of the phenomenon in the country, complemented by geographic studies where comparisons

143 Kinberg, Inghe, and Riemer 1943. 
were made regarding the prevalence of the crime of incest in different counties, or in the city versus the countryside. On an individual level, those who had been prosecuted and convicted of incest were studied from medical, psychological, and social perspectives. Their occupations and ages were noted, as was their physical and psychological health. The convicts and their families answered questions about their living conditions and sleeping habits. They described their alcohol-consumption habits and how their family dynamics worked. They also gave an account of their religious faith and whether they led a moral or immoral life.

According to the statistical results of these two studies, incest crimes were largely distributed among three relationship categories. Roughly half or a little more than half of incest crimes occurred between father and daughter, while stepfather/stepdaughter and sibling relationships each made up one quarter of the total. Other relationship combinations were very unusual. ${ }^{144}$ Furthermore, the investigations showed that the phenomenon of incest was overrepresented in the lowest social groups in society; for example, among unskilled labourers in the city and unpropertied farm workers in the countryside. ${ }^{145}$

Like many others belonging to the same social stratum, these families often lived in dysfunctional relationships and had significant economic problems. In several cases one or both parents were alcoholics, and the children were exposed to neglect and abuse of various kinds. ${ }^{146}$ In the Sondén study, the 'wide-spread objectionable custom' of family members sharing a bed was held up as a direct cause of incest crimes. ${ }^{147}$ In the Kinberg/Inghe/Riemer study, however, it was argued that this connection could not be proven. ${ }^{148}$ Even so, both investigations established that overcrowding in the social groups in question was problematic, that the 'typical incest offender' suffered from sexual abstinence, that certain psychological stresses might

144 Kinberg, Inghe, and Riemer 1943, p. 46; SOU 1935:68, p. 46.

145 Kinberg, Inghe, and Riemer 1943, p. 85; SOU 1935:68, p. 50.

146 In the Kinberg/Inghe/Riemer study, 'the inner disintegration of family life' was said to be characteristic of families where incest occurred. Fifty-five out of fifty-eight families lived in conditions that entailed a 'complete breakdown of family life' (Kinberg, Inghe, and Riemer 1943, pp. 105f). In the Sondén study, the misuse of alcohol in combination with other environmental factors (overcrowding) were presented as the major causes of the crime. SOU 1935:68, p. 51.

147 SOU 1935:68, p. 52.

148 Kinberg, Inghe, and Riemer 1943, p. 118. 
occur (even if the crime could not be directly linked to psychological disorders), and that an incest offender was not particularly criminally inclined. In some isolated cases, it turned out that the offender was regretful and ashamed of his actions after the fact; but far too often, the 'proper' moral insight was lacking. ${ }^{49}$

The empirical results corresponded to an ideological notion about the 'typical' sex offender. German forensic psychiatry emphasised both internal factors (mental illness or an abnormal sexual drive) and external factors (bad social conditions) as the causes of various sexual crimes; and historian Åsa Bergenheim has shown that Swedish doctors and forensic psychiatrists were strongly influenced by the ideas from Germany. ${ }^{150}$ According to these ideas, the crime of incest was more common among the lowest and most primitive citizens in society than among more cultured people. Similar ideas could be found among contemporaneous medical experts in Denmark and the United States. ${ }^{151}$ In France, the image of the incest perpetrator as a monster, an unnatural person, was established towards the end of the nineteenth century. Here, too, connections were made between incestuous acts and economic and cultural poverty. ${ }^{152}$

Whether the crime of incest can in fact be linked to social class may be questioned, though, as the number of unrecorded incest crimes is sure to grow along with a family's rising position in society. But this was not discussed at the time. ${ }^{153}$

In summary, the Swedish investigators affirmed that a poor childhood environment with an inferior cultural and moral education constituted a basic risk factor for incest crimes, which, in combination with a 'triggering factor' (sexual abstinence or the influence of alcohol), could drive people to commit an incestuous act. ${ }^{154}$ Alcohol was no longer a mitigating circumstance for the commission of criminal acts, a circumstance that may be linked to the fact that a temperance movement now had strong political support in Swedish society. ${ }^{155}$

149 SOU 1935:68, pp. 45, 51; Kinberg, Inghe, and Riemer 1943, pp. 126, 128, 181, 193, 195.

150 Bergenheim 1998, pp. 130f.

151 Seidelin 2014, pp. 86-8, and the literature referred to therein; Gordon 1986.

152 Formally speaking, incest was not defined as a criminal act in France. Giuliani 2008.

153 On hidden crimes of incest in the higher social classes in the United States, see Herman and Hirschman 1977.

154 SOU 1935:68, p. 51.

155 Nilsson 2008, pp. 138-42, $200 f$. 


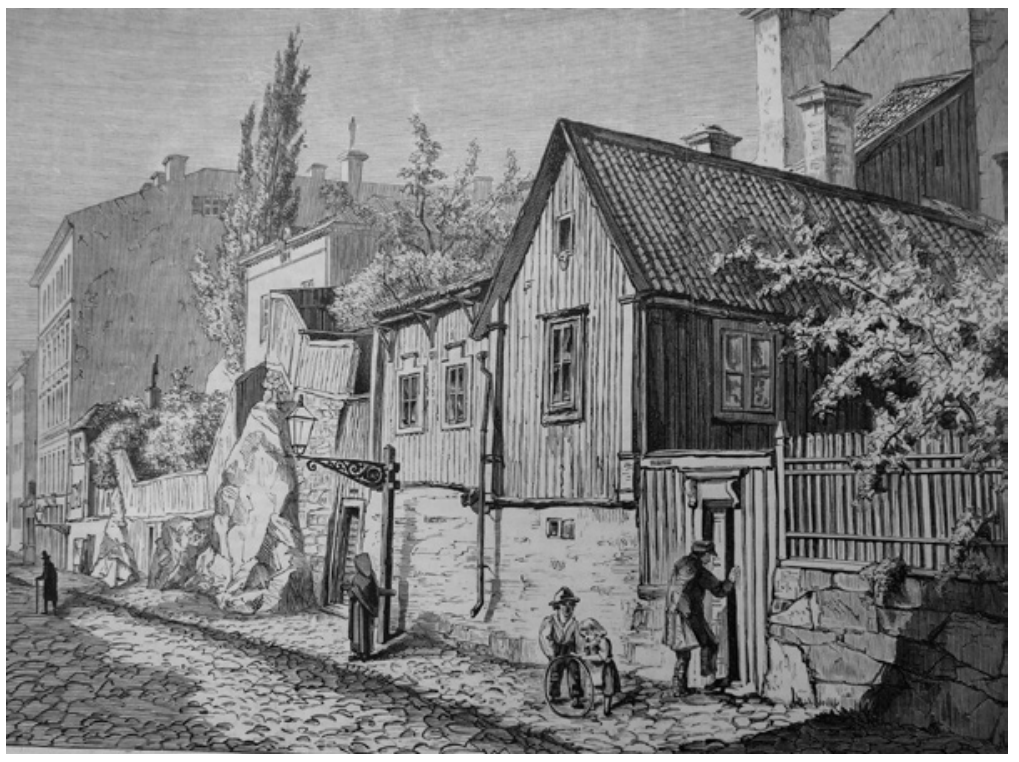

19 After the turn of the century in 1900, the majority of incest crimes discovered were committed in families from the lowest social strata. Incest hence came to be defined as a lower-class problem.

\section{Violence and exploitation}

When a number of affinity prohibitions were abolished at the end of the nineteenth century, the general picture of the crime of incest began to change. For centuries, the majority of these crimes had involved voluntary sexual relationships between adults. As the number of prohibitions decreased, the relationship categories that were dominated by voluntary relationships disappeared. Those relationships that tended to be the consequences of coercion and exploitation were still prohibited. Incest between members of a nuclear family had always provoked a particular revulsion, but those offences had constituted a minority of Swedish incest crimes, and these relationships were not the ones against which earlier laws had primarily been used. This fact might explain why it took so long before it became obvious to the authorities that incest between (step)parent and (step)child was often a matter of downright abuse.

Still, the above-mentioned investigations from the 1930s did draw attention to these circumstances. Kinberg, Inghe, and Riemer affirmed that voluntary incestuous relationships between adult individuals 
were 'very unusual'. Nor was it common for girls to behave seductively or provocatively, as had been claimed in other contemporaneous studies from abroad. ${ }^{156}$ The official investigation from 1935, which included the Sondén study, established that incestuous relationships were to a high degree a matter of crimes against minors or abuse of paternal authority. Not enough attention had been paid to this fact in earlier discussions, the investigators said, and this could not be 'emphasised too much'. ${ }^{157}$ Statistics showed that upwards of $75 \%$ of alleged incest crimes were committed by an older man and a younger girl. That the girls in these contexts were found to be accessories to the crime was regarded as extremely unfortunate, though the judges often allowed them to escape with a conditional sentence. The girls were, after all, sentenced for actions they had been forced to commit, and for this reason it was considered urgent for the legislation to be changed so that the protection for children and adolescents improved. ${ }^{158}$ As a direct consequence of this investigation, the legislation was changed two years later. Those who had been enticed or intimidated into committing incestuous acts because of a position of dependency or youth were henceforth made completely exempt from punishment. ${ }^{159}$

Even so, the 'objective harm' suffered by the victimised girls was considered to be relatively limited. This conclusion was justified by the belief that the children were already traumatised by the conditions of the environment in which they grew up, where quarrels and violence were everyday occurrences, as well as by the belief that their deficient moral education meant that they neither realised nor were particularly harmed by the abuse to which they were subjected. ${ }^{160}$ Following an analysis of incest crimes against Swedish children from 1850 to 1910, Bergenheim describes the existence of such beliefs. Even when a child claimed to be in pain, or when there was bruising, swelling, and discolouration of the genitals, the doctor would declare that there were no 'actual injuries'. The psychological condition of the child was not discussed at all. ${ }^{161}$ The child was thus considered free of guilt with respect

156 Kinberg, Inghe, and Riemer 1943, pp. 41, 249, quotation on p. 41.

157 SOU 1935:68, pp. 49f, 59.

158 SOU 1935:68, pp. 37, 55f. On the court's treatment of the victimised girls, see also Bergenheim 1998, pp. $136 \mathrm{f}$.

159 Semmler 2003, p. 10.

160 Kinberg, Inghe, and Riemer 1943, pp. 316, 331.

161 Bergenheim 1998, pp. $136 \mathrm{f}$. 
to the criminal act, but was not felt to suffer any real harm from the crime.

But it was not only the younger party who was perceived as a potential victim at this time. Environmental factors and other circumstances related to a person's upbringing were given such a prominent place as an explanatory basis for incest that not even the initiator of the crime could be held completely responsible for his actions. In cases where an individual had grown up in a bad environment and there was some triggering factor (alcohol or sexual abstinence), the individual in question was seen as virtually predestined to engage in incestuous behaviour. The study by Kinberg, Inghe, and Riemer found that incest might develop 'from a constellation of circumstances' where the incest offender was a 'victim' rather than a free agent. ${ }^{162}$ The crime was described as the extreme effect of 'an advanced social and moral decay', against which society should have taken action long before. The strict legislation was regarded as being too severe towards these 'disadvantaged and pitiable people' who had grown up and lived in 'economic, social, and moral destitution'. ${ }^{163}$

Here the investigators were evidently influenced by contemporary eugenic as well as sexological ideas. Incest offenders were described as 'psychologically and socially underdeveloped in comparison to other people, who [were] born into a happier environment and were better equipped biologically'. ${ }^{164}$ They were thought to exist in a parallel, culturally impoverished, proletarian stratum of society which had evolved as an unhappy consequence of industrialisation. They were also considered to be at the mercy of their own biology and their heightened male sexual drive, which might compel them to commit incestuous acts in the event of sexual abstinence. They were, in other words, victims of their environment, their culture, and their natural urges.

Paradoxically enough, the development outlined above amounted to a complete reversal in the basic attitude to incest offenders. Previously, both parties had been considered to be equally responsible for the crime, regardless of their ages or social circumstances; now they were both to a large extent regarded as victims of their culturally impoverished environment and their biology, which partly exempted them from responsibility for committing the acts. This

162 Kinberg, Inghe, and Riemer 1943, pp. $286 f$.

163 Kinberg, Inghe, and Riemer 1943, p. 289.

164 Kinberg, Inghe, and Riemer 1943, pp. $297 f$. 
line of reasoning also led to a recommendation that the sentences be reduced. In order to prevent future incest crimes it was, among other things, recommended that the already ongoing sterilisations of 'oligophrenic' or psychologically inferior individuals should be made more efficient, while societal efforts should improve the environment in which children were brought up. ${ }^{165}$ This view was completely in line with contemporary criminological explanatory models, where attention was paid to social circumstances as a cause of criminal behaviour. ${ }^{166}$

\section{Voluntary relationships}

Though relationships based on violence and exploitation dominated incest crimes during the early twentieth century, there were examples of couples who voluntarily initiated sexual relations in violation of the law. How did the authorities and the community react to these forbidden relationships?

In December 1915, Oskar Nordström (thirty-two years old) and his half-niece Johanna Blomqvist (twenty-one years old) were accused of incest. The relationship had been initiated three years earlier, when Johanna was employed as a housekeeper for Oskar, and the couple now had two children together. They claimed that they had not understood that they were acting in opposition to the law because Oskar was only the half-brother of Johanna's mother. The prosecutor petitioned for a mild punishment and the couple were sentenced to a fine. Seven months later they applied for a dispensation for marriage, which was granted. ${ }^{167}$

Under similar circumstances, Ester Johansson (twenty-four years old) moved in with her uncle, butcher Karl Johansson (forty-one years old), to help him with his housekeeping. After a year or so they began a sexual relationship which resulted in two children. Before Ester moved in, Karl was said to have led an 'intemperate

165 Kinberg, Inghe, and Riemer 1943, pp. 337-49.

166 Häthén 1990, p. 221; Bergenheim 1998, pp. 127-31. The trend within criminal policy that emphasised the importance of a criminal's predispositions in combination with his or her social environment was referred to as 'the positive school' and was primarily inspired by Italian professor of criminology Enrico Ferri. Inger 2011, pp. 293, 305, 308.

167 Råneå hundred, AIa:130 1915, 5 October, no. 39; 6 December, no. 69; JD, Cabinet-meeting document, 1915, 22 December, no. 31; JD, R, K, 1915, 22 December, Oskar Nordström, Johanna Blomqvist. 
and disorderly life'; but she apparently had a good effect on him, and she had taken on the care of the home, the children, and Karl's invalid parents in a 'commendable manner'. In 1913, the couple applied for a dispensation for marriage but had their application rejected. In spite of the rejection, they continued to live together. About a year later, Ester's sister Ebba (seventeen years old) moved in with the family, and within a short period of time she too was enticed into having sexual relations with Karl. When Ester found out, she temporarily left the home but returned after a week or so. Shortly thereafter they were all arrested, accused of incest. ${ }^{168}$

The arrest was occasioned by a formal letter in which it was claimed that the butcher in the village had 'for a long time' lived with his niece and that they had children together. The relationship had not been openly admitted to, but according to the writer of the letter 'everyone' in the neighbourhood knew what was going on. The report was made in the hope that the 'chastisement prescribed by law' might be visited on the couple and that their 'deplorable relationship' might come to an end. The 'deplorable' aspect of the relationship seems only to refer to the family relationship. The fact that Ester's sister Ebba had also begun a sexual relationship with Karl is not mentioned in the letter, and whether this was known in the community is uncertain. All the people involved 'freely and without coercion' confessed their participation in the crime, whereupon Karl was sentenced to six months of hard labour for each crime of incest, that is to say a year in total. Ester and Ebba were given a conditional sentence of one month's imprisonment after their lawyer had pointed out that neither of them had been over the age of eighteen when the incestuous relationships began; that it might be questioned whether the family relationship could really be considered to be offensive, in that the new law permitted dispensations for marriage for the same kinship category; and that Ester's children risked faring badly if Ester was given a more severe punishment. ${ }^{169}$ As in the previous case, Karl, Ester, and Ebba were thus sentenced to relatively mild punishments.

The man who reported the crime to the authorities was no doubt offended by the family relationship between Ester and Karl, but it had taken him a long time to act. Karl and Ester's first child was born in 1909, and after this event everybody ought to have realised

168 Västra Göinge hundred, AIb:32, 1915, 8 October, no. 16.

169 Västra Göinge hundred, AIb:32, 1915, 8 October, no. 16; HSoB, BIIc:236, 1915:2, 1 November, no. 301. 
that Ester was more than simply his housekeeper. The couple lived together for over six years before they were reported to the authorities. Once more, then, the picture of a passive local community emerges - a community where people certainly gossiped in private, but took no active measures in order to remedy the situation. This passive attitude was, according to Kinberg, Inghe, and Riemer, common even when the younger party was obviously the victim of abuse. The authors point out that the public primarily reacted emotionally to incestuous relationships. People were horrified at the situation, and at the same time they felt a forbidden temptation to know more about the relationship in question. For this reason, it was common for prohibited relationships to go on for years while the community watched the actions of the persons involved from a distance, gossiping in whispers about what they had seen. ${ }^{170}$ The community was in other words reluctant to 'interfere' in what they perceived to be private affairs.

This passivity can be recognised from previous periods. In the past, most incest crimes were brought to light when the woman became pregnant; but during the early twentieth century, it was only every fifth crime that was brought to the authorities' attention because of a pregnancy. ${ }^{171}$ This change is probably due to the fact that sexuality was less strictly controlled and that it was considerably more common for women to bear children outside marriage - especially in the lower social strata, which is where the majority of incest crimes were discovered.

Incestuous relationships based on genuinely warm feelings between the accused parties seem always to have been supported by the immediate community, and from the nineteenth century onward they were also treated more leniently by the authorities. Reader of psychiatry Torsten Sondén, who was responsible for parts of the official inquiry of 1935, called these relationships 'the idyllic type'. He described situations where a 'truly mutually affectionate relationship' had developed between a man and a woman. This usually involved a stepfather and his stepdaughter after the man had been widowed. In a few such cases, the people in question had wanted to marry and had become engaged, believing that their relationship was completely legal because there were no biological ties between them. This misconception was, according to Sondén, 'fairly common [...] among the population in Sweden'. Some couples had also been

170 Kinberg, Inghe, and Riemer 1943, pp. 266-8.

171 Kinberg, Inghe, and Riemer 1943, p. 269. 
supported in their relationship by a clergyman or a lawyer who recommended that they apply to the king for a dispensation for marriage. Their disappointment was great when they realised that the law regarded the family relationship as a marriage impediment 'for which a dispensation cannot be granted'. ${ }^{172}$ The investigators argued that these individuals should not be punished as severely as those who had committed crimes of incest under other circumstances. Apart from safeguarding the legal rights of children and adolescents, the investigators therefore also wished to differentiate the penalties imposed so that it would be possible to distinguish 'aggravated' incest cases from 'less serious' ones. ${ }^{173}$

A certain differentiation among the legal penalties was conceded as early as the Act of 1864 , and the cases previously referred to have shown that judges used the opportunity to reduce sentences in practice. In addition, the 1937 revision of the law introduced two separate ranges of punishment in order to distinguish between aggravated crimes of incest and those that were not so serious.

Sondén's claim that people in general thought that only biological family relationships were forbidden is supported by examples from the Kinberg/Inghe/Riemer study. One man expressly stated that he could not be defined as a sexual offender because he was not related to the woman in question, who was his stepdaughter. ${ }^{174}$ Similarly, the preceding section showed that the absence of biological kinship ties was foregrounded as an argument for having applications for dispensation approved. Even though people occasionally claimed to be ignorant of other incest prohibitions too, the main dividing line seems to run between biological and non-biological family relationships. ${ }^{175}$ Consequently, the definition of family and kinship had once more ended up at the centre of attention when the limits of incest prohibitions were negotiated. While some people felt that a stepfather and stepdaughter should definitely be regarded as relatives, other people argued that only people with biological kinship ties should be considered to be related to each other. The sharper focus on biological kinship was probably a result of the increased importance of medical science in society.

Just as in earlier periods, there was a grey zone between legal and illegal relationships where the legislation set a boundary that

172 SOU 1935:68, pp. 53f.

173 SOU 1935:68, pp. 37, 59f, quotation on p. 37.

174 Kinberg, Inghe, and Riemer 1943, p. 237. See also pp. 384, 391.

175 Kinberg, Inghe, and Riemer 1943, pp. 236, 262. 
was not always known or accepted by the wider public. It is hence possible to distinguish a general trend over time, a trend according to which those prohibitions that were most distant from ordinary life at any one time were simply unknown to some people. In other words, the liberalisations that have been implemented were always preceded by increased cultural acceptance. It should, however, be added that the relationship in the diagonal consanguinity degree (aunt, niece) forms an exception. This kinship is biological; and although it was argued around 1900 that Sweden should abolish this incest prohibition, like Denmark, Norway, and Germany, there was both knowledge of and an acceptance of the fact that this family relationship constituted a potential impediment. Sexual relations between couples in the diagonal consanguinity degree were decriminalised in 1937, but the marriage prohibition remained until $1973 .{ }^{176}$

\section{Partial summary and overview, 1840-1940}

During the course of the nineteenth century, the importance of religion in the public sphere in Sweden continued to wane. One consequence of this development was that the penalties for incest crimes could be reduced. At the same time, the tolerance for horizontal and diagonal affinity relationships kept growing. The number of applications for dispensation rose steadily, and they were routinely approved. In addition, more and more people chose to live openly together in defiance of the law. Recurring discussions in the Riksdag finally led to several affinity prohibitions being abolished in 1872 . The proportion of voluntary relationships hence declined among the incest crimes, and this made incest appear more of a crime of violence than a moral crime.

Around the turn of the century in 1900, race-biological ideas also came to be of great importance in the assessment of incest cases in Sweden. Medical science was gaining ground, and discussions on impediments to marriage would now include references to medical and genetic conditions. Besides, the debate contained hints of socialDarwinist notions which tied people's social positions to their biological inheritance. Those who had been equipped with 'good' genes were believed to manage better in society than those who had been saddled with 'inferior' ones. Since most of the incest crimes that

176 Kinberg, Inghe, and Riemer 1943, p. 278; Tottie 1974, pp. 25, 176. 
were discovered around the turn of the century in 1900 were committed by individuals from the lowest social groups, the crime came to be perceived as a lower-class problem. Being children of 'unfit' parents, and lacking clear moral governance during their childhood and adolescence, incest criminals were described as victims of both their biology and their environment.

In order to harmonise Nordic legislation, an opportunity for people to apply for dispensation to marry in the diagonal consanguinity degree (aunt, niece) was introduced in 1915. In accordance with the new race-biological way of thinking, however, detailed medical examinations and descriptions of the family background were required for these applications to be approved. Even though it was the kinship in itself, and the health hazards that it was thought to entail, that dominated the theoretical incest debate in Sweden at this time, it was - surprisingly enough - not these issues that determined the decisions on permissions to marry. Instead, the authorities focused on the age relationship between the applicants, rejecting applications from couples where the age difference was greater than twenty years. Although there were no legal restrictions, the authorities thus chose to act in accordance with informal norms according to which spouses should be of the same age.

Once more, it becomes obvious that the handling of incest cases was to a great extent governed by informal norms in society. These norms were rarely specific to Sweden. Similar ideas could be found in several European countries. Developments in the other Nordic countries, in Germany, and in Austria were similar to those in Sweden, even though the countries on the continent were often a couple of decades ahead of the Nordic countries. In all areas, incest prohibitions were debated on the basis of secular ideas in which the view on the family and on social morality was crucial. Tolerance for marriages between related individuals increased while the number of prohibitions decreased. Incest crimes discovered at the turn of the century in 1900 were often linked to social problems in the lower social groups, to poverty and immorality. ${ }^{177}$

In Britain, marriages between biological cousins were permitted, but not between a man and his wife's sister. In spite of this prohibition, such marriages did occur; but they were vulnerable because the legitimacy of the relationship could be questioned after the fact. If the marriage was declared invalid, any children would lose their

177 Jarzebowski 2012; Saurer 1997. 
right of inheritance. In 1835, the British Parliament passed a proposal for legislation which meant that all marriages that had been entered into between related individuals before 1835 should be considered legitimate. The aim of this proposed legislation, Lord Lyndhurst's Act, was to protect the legitimacy of previously contracted marriages. Instead, however, it launched an animated debate that lasted for a hundred years. Over time support for cousin marriages diminished, partly because of the race-biological ideas that were spreading all over Europe; and at the beginning of the twentieth century, these relationships exchanged status. The prohibition against marriages between brothers-in-law and sisters-in-law was abolished in 1907, and the following year cousin marriages were forbidden. ${ }^{178}$ In turnof-the-century Britain, too, race-biological debates led to incest being linked to poverty and immorality. ${ }^{179}$

In contrast to other countries, incestuous relationships were not illegal in France after 1791. As a consequence, incest became invisible during the greater part of the nineteenth century. The community did not interfere in what happened behind the family's closed doors. Not until towards the end of the century, when the race-biological debate had been going on for a couple of decades, did public opinion wake up. Now incestuous acts were condemned as being unnatural, and they came to be linked to poverty and immorality in the same way as in other European countries. ${ }^{180}$ While the problem of incest was the subject of animated debate in Britain throughout the nineteenth century, the issue was all but suppressed in France. Even so, these countries ended up taking similar positions around the turn of the century in 1900 .

The similarities across national borders were considerably greater than the differences. The position of religion changed everywhere, the proportion of marriages between related individuals rose, and medical science obtained increased influence. Everywhere, too, developments were variously affected by ideas of race biology. These ideas were partly connected to social circumstances, the crime of incest being singled out as a distinctly social problem among the poor, and partly to new definitions of the family: now there was a distinct dividing line between the biological and the non-biological.

178 Kuper 2009, pp. 66-92. Denbo 2001, pp. 182-7.

179 Kuper 2002, pp. 180-3.

180 Giuliani 2008. 